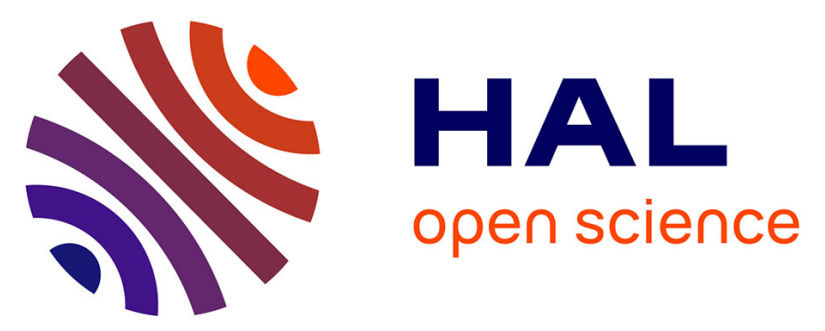

\title{
RIPK1 protects hepatocytes from Kupffer cells-mediated TNF-induced apoptosis in mouse models of PAMP-induced hepatitis
}

Aveline Filliol, Claire Piquet-Pellorce, Céline Raguénès-Nicol, Sarah Dion, Muhammad Farooq, Catherine Lucas-Clerc, Peter Vandenabeele, Mathieu J.

M. Bertrand, Jacques Le Seyec, Michel Samson

\section{To cite this version:}

Aveline Filliol, Claire Piquet-Pellorce, Céline Raguénès-Nicol, Sarah Dion, Muhammad Farooq, et al.. RIPK1 protects hepatocytes from Kupffer cells-mediated TNF-induced apoptosis in mouse models of PAMP-induced hepatitis. Journal of Hepatology, 2017, 66 (6), pp.1205-1213. 10.1016/j.jhep.2017.01.005 . hal-01532060

HAL Id: hal-01532060

https://hal-univ-rennes1.archives-ouvertes.fr/hal-01532060

Submitted on 8 Jun 2018

HAL is a multi-disciplinary open access archive for the deposit and dissemination of scientific research documents, whether they are published or not. The documents may come from teaching and research institutions in France or abroad, or from public or private research centers.
L'archive ouverte pluridisciplinaire HAL, est destinée au dépôt et à la diffusion de documents scientifiques de niveau recherche, publiés ou non, émanant des établissements d'enseignement et de recherche français ou étrangers, des laboratoires publics ou privés. 
Title: RIPK1 protects hepatocytes from Kupffer cells-mediated TNF-induced apoptosis in models of PAMP-dependent hepatitis

\section{Short title: Protective role of RIPK1 in PAMP-dependent hepatitis}

Aveline Filliol ${ }^{1,2,3}$, Claire Piquet-Pellorce ${ }^{1,2,3}$, Céline Raguénès-Nicol ${ }^{1,2,3,7}$, Sarah Dion $^{1,2,3}$, Muhammad Farooq ${ }^{1,2,3}$, Catherine Lucas-Clerc ${ }^{2,4}$, Peter Vandenabeele ${ }^{5,6}$, Mathieu JM Bertrand ${ }^{5,6}$, Jacques Le Seyec ${ }^{1,2,3}$ and Michel Samson ${ }^{1,2,3}$.

${ }^{1}$ Institut National de la Santé et de la Recherche Médicale (Inserm), U.1085, Institut de Recherche Santé Environnement et Travail (IRSET), F-35043 Rennes, France.

${ }^{2}$ Université de Rennes 1, F-35043 Rennes, France.

${ }^{3}$ Structure Fédérative BioSit UMS3480 CNRS-US18 Inserm, F-35043 Rennes, France.

${ }^{4}$ Service de Biochimie CHU Rennes, Université de Rennes 1; F-35043 Rennes, France.

${ }^{5}$ Inflammation Research Center, VIB, Technologiepark 927, Zwijnaarde-Ghent, 9052, Belgium.

${ }^{6}$ Department of Biomedical Molecular Biology, Ghent University, Technologiepark 927, Zwijnaarde-Ghent, 9052, Belgium.

7 Centre National de la Recherche Scientifique (CNRS), UMR 6290, Institut de Génétique et Développement de Rennes (IGDR), F-35043 Rennes, France.

Correspondence: Michel Samson, INSERM-U1085, IRSET, Université de Rennes 1, 2, Avenue du Professeur Léon Bernard, 35043 RENNES Cedex, France. Phone (+33) 223235927 ; Fax (+33) 223234794.

Word count of manuscript:

Number of figures: 6 (main figures) +3 Supplementary figures

\section{Number of tables: 0}

Financial support: This work was supported by INSERM, the Ministère de l'Education Nationale de la Recherche et de la Technologie, the University of Rennes 
1, the Région Bretagne, the "Ligue contre le cancer, comités du grand Ouest".

a. Conflict of interest.

Aveline Filliol declares no financial or commercial conflict of interest.

Claire Piquet-Pellorce declares no financial or commercial conflict of interest.

Céline Raguénès-Nicol declares no financial or commercial conflict of interest.

Sarah Dion declares no financial or commercial conflict of interest.

Muhammad Farooq declares no financial or commercial conflict of interest.

Catherine Lucas-Clerc declares no financial or commercial conflict of interest.

Peter Vandenabeele declares no financial or commercial conflict of interest.

Mathieu JM Bertrand declares no financial or commercial conflict of interest.

Jacques Le Seyec declares no financial or commercial conflict of interest.

Michel Samson declares no financial or commercial conflict of interest.

\section{b. Authors' contributions}

Aveline Filliol : acquisition of data; analysis and interpretation of data, statistical analysis, drafting of the manuscript

Claire Piquet-Pellorce : acquisition of data, analysis and interpretation of data

Céline Raguénès-Nicol : acquisition of data, drafting of the manuscript

Sarah Dion : acquisition of data, drafting of the manuscript

Muhammad Farooq : acquisition of data, drafting of the manuscript

Catherine Lucas-Clerc : obtained technical or material support

Peter Vandenabeele : obtained material support, critical revision of the manuscript for important intellectual content

Mathieu JM Bertrand : drafting of the manuscript, obtained material support, critical revision of the manuscript for important intellectual content

Jacques Le Seyec : acquisition of data, statistical analysis, interpretation of data, drafting of the manuscript

Michel Samson : acquisition of data, analysis and interpretation of data, statistical analysis, drafting of the manuscript, study concept and design, study supervision 


\section{ABSTRACT (227 words)}

\section{Background \& Aims}

The severity of liver diseases is exacerbated by the death of hepatocytes, which can be induced by the sensing of Pathogen Associated Molecular Patterns (PAMPs) derived from the gut microbiota. The molecular mechanisms regulating these cell death pathways are poorly documented. In this study, we investigated the role of the Receptor Interacting Protein Kinase 1 (RIPK1), a protein known to regulate cell fate decisions, in the death of hepatocytes using two in vivo models of PAMP-induced hepatitis.

\section{Methods}

Hepatitis was induced in mice by independent injections of two different bacterial PAMPS: lipopolysaccharide (LPS) and unmethylated CpG oligodeoxynucleotide (CpG-DNA) motifs. The role of RIPK1 was evaluated by making use of mice specifically lacking RIPK1 in liver parenchymal cells (Ripk $1^{\text {LPC-KO }}$ ). Administration of clodronate encapusated-liposome served to investigate the role of Kupffer cells in the establishment of the disease. Etanercept, a Tumor Necrosis Factor (TNF)-decoy receptor, was used to study the contribution of TNF- $\alpha$ during LPS-mediated liver injury.

\section{Results}

Whereas RIPK1 deficiency in liver parenchymal cells did not trigger basal hepatolysis, it greatly sensitized hepatocyte to apoptosis and to liver damages following single injection of LPS or CpG-DNA. Importantly, hepatocyte death was prevented by previous macrophage depletion or by TNF inhibition. 


\section{Conclusions}

Our data highlight the pivotal function of RIPK1 in maintaining liver homeostasis in conditions of macrophage-induced TNF burst in response to PAMPs sensing.

\section{Lay summary}

An excessive hepatocyte death is a characteristic of liver injury. A new programmed cell death pathway has been described involving upstream death ligands such as TNF and downstream kinases such as RIPK1. Here, we show that in the presence of LPS in liver induced hepatic injury due to secreted of TNF by liver macrophages and that RIPK1 is a powerful protector of hepatocyte death. This newly identified pathway in liver may therefore be helpful in the management of patients in the prediction of their risk to develop acute liver failure.

Keywords: Cytokine, Acute Hepatitis, RIP kinase, RIPK1, TNF- $\alpha$, LPS, CpG-DNA, PAMPs, DAMPs, Liver, Inflammation, cell death.

List of abbreviations: ACLF: Acute on chronic liver failure, AST: aspartate aminotransferase, ALT: alanine amino-transferase, $\mathrm{Cl}_{2} \mathrm{MBP}$ : dichloromethylene bisphosphonate, Cl-Caspase3: Cleaved-Caspase3, DAMP: Damage Associated Molecular Pattern, DC: dendritic cells, D-GalN: D-Galactosamine, DR: death receptor, ETA: Etanercept, H\&E: hematoxylin and eosin coloration, IHC: Immunohistochemistry, i.p: Intraperitoneal, KC: kupffer cells, LPS: lipopolysaccharide, LSEC: Liver sinusoïdal endothelial cells, NASH: nonalcoholic fatty liver hepatitis, ODN: oligodeoxynucleotide, PAMP: Pathogen associated molecular patterns, p.i.: Post injection, RIPK: receptor interacting protein kinase, TLR: toll like receptor, TNF: tumor necrosis factor. 


\section{INTRODUCTION}

The liver is constantly exposed to bacterial Pathogen Associated Molecular Patterns (PAMPs) such as unmethylated CpG-DNA motifs or lipopolysaccharides (LPS) originating from the microbiota of the gastrointestinal tract. In physiological condition, the intestinal barrier prevents the translocation of large amount of bacterial byproducts to the liver [1]. The low quantities of bacterial debris reaching the liver are efficiently cleared by phagocytic hepatic cells, which avoids induction of inflammation and harmful response [2]. In chronic liver diseases of steatosic or alcoholic origin, this intestine barrier function is damaged [3] [4] resulting in an abnormal elevation of PAMPs in the liver and impairing liver homeostasis [5]. PAMPs increase in the liver is one of the most common factor responsible for the outbreak of acute hepatitis on chronic liver failure background (ACLF for acute on chronic liver failure) [6]. According to the European Association for the Study of Liver Disease (EASL) and the Asian Pacific Association for the Study of the Liver (APASL), ACLF is an acute deterioration of pre-existing chronic liver diseases, and as a consequence, can provoke high short-term mortality. Thus, ACLF is, today, one of the most challenging fields in hepatology [7]. However, the molecular mechanisms responsible for the liver failure are incompletely understood.

Due to its anatomical link with the gut, the liver plays a key role in the bacterial clearance, which explains why $\sim 80 \%$ of macrophages are in the liver [5] [8]. These liver resident macrophages, named Kupffer cells (KC) efficiently phagocytose bacteria and eliminate endotoxins in order to avoid systemic bacterial infection [5]. In addition to phagocytosis, $\mathrm{KC}$ are among the first cells to initiate the inflammatory response through the sensing of microbial products by the toll like receptors (TLRs) expressed at their surface or within their endosomes [8]. For example CpG-DNA and 
LPS respectively activate TLR9 and TLR4. Activation of TLRs contributes to ACLF by triggering an inflammatory response. Thus, LPS has been shown to contribute to cirrhosis, autoimmune hepatitis, primary biliary cirrhosis, alcoholic and fatty liver diseases both in humans and mouse models [9] [10] [11] [5]. Among proinflammatory cytokines released by LPS-activated-KC, TNF- $\alpha$ has emerged as a key factor in the inflammatory process, as levels of soluble TNF receptors correlate with endotoxin influx and liver injury [12] [13]. In mice, LPS intraperitoneal administration induces a systemic inflammatory response that can lead to death by septic shock, without inducing liver injury [14]. However, administration of LPS in a dietary NASH model or in combination with the hepatotoxic D-Galactosamine (D-GalN) in mice induces hepatocyte apoptosis in a TNF- $\alpha$-dependent manner [15] [16]. D-GalN is metabolized into an active metabolite exclusively in hepatocytes and inhibits transcription by hepatic uridine nucleotide depletion [17]. Thus, it has been widely described that in the liver, NF-kB or transcription inhibition sensitizes hepatocytes to TNF- $\alpha$-mediated apoptosis [18] [16] [19]. However, due to the pleiotropic role of TNF- $\alpha$, anti-TNF- $\alpha$ therapeutic strategies in patients with alcoholic hepatitis are associated with an increased risk of infection and mortality [20] [21]. The Receptor Interacting Protein Kinase 1 (RIPK1) plays key roles in the signaling of several death receptors (DR) such as TNFR1 by deciding the cell fate between survival and death [22]. It has been recently reported that RIPK1 is implicated in epithelial cell death in intestine in TNF $\alpha$ and bacterial dependent manner [23]. As its role in the liver is poorly understood, we address here the potential role of RIPK1 in hepatocyte death induced by PAMPs and relayed by TNF- $\alpha$, taking advantage of a knockout mouse line invalidated for the RIPK1 expressed in liver parenchymal cells (Ripk1 $1^{\text {LPC-KO}}$ ). 


\section{MATERIAL AND METHODS}

\section{Animals and treatment protocols}

Ripk $1^{\text {LPC-KO }}$ mouse model has been previously developed [24]. LPS (Sigma-Aldrich, \#L6761) diluted at $2 \mu \mathrm{g} / \mathrm{mL}$ in PBS was administrated by intraperitoneal (i.p.) route (20 $\mu \mathrm{g} / \mathrm{kg}$ body weight and $200 \mu \mathrm{L} / 20 \mathrm{~g}$ ). Unmethylated CpG oligodeoxynucleotide (ODN) (Invivogen, ODN 2395) diluted at $3.5 \mathrm{mg} / \mathrm{mL}$ in PBS was administrated by i.p. route $(2 \mathrm{mg} / \mathrm{kg}$ body weight and $200 \mu \mathrm{L} / 20 \mathrm{~g}$ ). Etanercept (Pfizer) was administrated by i.p. route $1 \mathrm{~h}$ before LPS injection (10 mg/kg body weight and $200 \mu \mathrm{L} / 20 \mathrm{~g}$ ). Two injections of liposomes-encapsulated dichloromethylene bisphosphonate $\left(\mathrm{Cl}_{2} \mathrm{MBP}\right)$ (see below for the preparation) were administrated by i.p. route in mice. The first injection was given with $200 \mu \mathrm{L} / 20 \mathrm{~g}$ body weight, and the second, $24 \mathrm{~h}$ after the first, with $100 \mu \mathrm{L} / 20 \mathrm{~g}$ body weight. Mice were administrated with LPS or control (PBS) 48 $\mathrm{h}$ after first injection of liposomes encapsulated $\mathrm{Cl}_{2} \mathrm{MBP}$ and sacrificed $8.5 \mathrm{~h}$ after LPS injection. In all experiments, genetically modified mice were systematically compared to their littermates. Mature mice at 10-12 weeks of age were used for each experiments. Animals were housed in individually ventilated cages at the VIB Inflammation Research Center (Ghent, Belgium) in conventional animal facilities. All experiments on mice were conducted according to institutional, national and European animal regulations. In vivo protocols were approved by the ethics committee of Ghent University.

\section{Genotyping}

Genotyping was routinely performed using DNA extracted from tails with Nucleospin Tissue kit (Macherey Nagel, \#740952), and PCR with couple of primers for Alfp-Cre 
gene. Forward and reverse primers sequences were 5'-GCC TGC ATT ACC GGT CGA TGC AAC GA-3' and 5'-GTG GCA GAT GGC GCG GCA ACA CCA TT-3', respectively.

\section{Preparation of liposomes-encapsulated $\mathrm{Cl}_{2} \mathrm{MBP}$ ( $\mathrm{Lip}-\mathrm{Cl}_{2} \mathrm{MBP}$ )}

Liposomes-encapsulated $\mathrm{Cl}_{2} \mathrm{MBP}$ were prepared according to Rooijen [25]. In brief, $86 \mathrm{mg}$ of phosphatidylcholine (Sigma-Aldrich) and $9 \mathrm{mg}$ of cholesterol (SigmaAldrich) were dissolved in chloroform in a round bottom flask. After $4 \mathrm{~h}$ on a gentle rotation on a rotary evaporator at $37^{\circ} \mathrm{C}$ and under reduced pressure, the thin film formed was resuspended with $10 \mathrm{~mL}$ of PBS, and $1 \mathrm{~g}$ of $\mathrm{Cl}_{2} \mathrm{MBP}$ (Sigma-Aldrich). After vigorous shaking for $1 \mathrm{~min}$, liposomes in the saturated $\mathrm{Cl}_{2} \mathrm{MBP}$ solution were extruded through $1 \mu \mathrm{m}$ diameter pores, followed by centrifugation at 10,000 $\mathrm{g}$ for $1 \mathrm{~h}$. The Lip-Cl ${ }_{2}$ MBP were washed 3 times with PBS with centrifugations at 22,000 g during $30 \mathrm{~min}$, and resuspended with $4 \mathrm{~mL}$ of PBS. The size measurement of Lip$\mathrm{Cl}_{2} \mathrm{MBP}$ was checked by Dynamic Light Scattering (DLS) technology (Zeta Sizer Nanoseries, Malvern) and as expected, $95 \%$ of the liposome had $1 \mu \mathrm{m}$ diameter. The Lip- $\mathrm{Cl}_{2} \mathrm{MBP}$ solution was diluted by half in PBS just before injection.

\section{Histopathological and biochemical studies}

Fragments of mouse livers were fixed in $4 \%$ paraformaldehyde and embedded in paraffin for $\mathrm{IHC}$ and hematoxylin and eosin (H\&E). For histopathology, H\&E staining of liver tissues was carried out to investigate liver injury. Serum ALT and AST transaminases were measured according to the IFCC primary reference procedures using Olympus AU2700 Autoanalyser ${ }^{\circledR}$ (Olympus Optical, Tokyo, Japan). 


\section{Immunolocalization in liver tissues}

For immunolocalization of cleaved caspase-3 (Cell Signaling) or myeloperoxidase (MPO) (Dako, \#A0398) in liver tissues, paraffin-embedded mouse liver sections (5 $\mu \mathrm{m}$ ) were dried $1 \mathrm{~h}$ at $58^{\circ} \mathrm{C}$, followed by antigen retrieval and incubated with primary antibody (Cell Signaling, 9661S) in a Ventana automated instrument (Ventana Medical Systems, USA). Revelation of primary antibody was carried out using horseradish peroxidase (HRP)-conjugated secondary antibody (Dako, USA) and DAB substrate kit (Ventana, \#760-124). Slides were then counterstained with hematoxylin.

TUNEL analysis was performed on paraffin-embedded mouse liver sections $(5 \mu \mathrm{m})$, incubated after antigen retrieval with a mix, composed of terminal transferase (Roche, \#3333566011) and digoxigenin-11-UTP (Roche, \#1558706) followed by HRP-anti-digoxigenin (Ventana, \#760-4822). Revelation was used according to the manufacturer with the Discovery Rhodamine kit (Ventana \#760-233) followed by nucleus labelling with DAPI.

All paraffin-embedded mouse liver sections were scanned with a digital slide scanner (Hamamatsu, Nanozoomer 2.0-RS) and files were analysis with the NDP viewer software.

TNF- $\alpha$ and F4/80 immunofluorescence staining were performed on cryosections of mouse liver tissues $(7 \mu \mathrm{m})$. After fixation with $4 \%$ paraformaldehyde and $\mathrm{NH}_{4} \mathrm{Cl}$ treatment, liver slides were blocked with $4 \%$ of BSA and then incubated with rabbitanti-murine TNF- $\alpha$ (Abcam, \#ab6671) and rat-anti-murine-F4/80 (eBioscience, \#47$4801-80)$ at $4^{\circ} \mathrm{C}$ overnight. Revelation of primary antibodies was carried out using DyLight 649-conjugated anti-Rabbit and DyLight 549 anti-rat IgG secondary 
antibodies (Jackson ImmunoResearch Laboratories). Nuclei were stained with Hoechst (Invitrogen, H3570). Slides were observed with a fluorescence microscope (Nikon's Eclipse Ni-E).

\section{Isolation of liver F4/80 positive cells and RNA analysis.}

Liver from PBS or LPS treated mice was collected $1.5 \mathrm{~h}$ post-injection and crushed on a $70 \mu \mathrm{m}$ filter. Liver immune cells were isolated after sedimentation and cell fractionation on a $35 \%$ Percoll layer and red blood cells were lysed with the ammonium-chloride-potassium (ACK) buffer. In order to isolate F4/80 positive cells, we used the MagniSort Mouse F4/80 positive selection kit (eBioScience, \#88026863-74) and followed the manufacturer protocol. Quickly, liver immune cells were incubated with anti-F4/80 antibodies and biotin-magnetic beads. To eliminate F4/80 negative cells, samples were incubated 3 times in a magnet separated by washes steps. Next, F4/80 positive cells were pelleted and stored dry at $-80^{\circ} \mathrm{C}$ before RNA extraction.

In order to measure cell transcripts, messenger RNA (mRNA) from 50000 F4/80 positive cells were extracted with the NucleoSpin RNA XS kit (Macherey Nagel, \#740902). Next, first-strand cDNA was synthesized using the SuperScript ${ }^{\mathrm{TM}}$ II Reverse Transcriptase (Applied Biosystems, \#4368813) and real-time quantitative PCR was performed using the fluorescent dye SYBR Green with the double-strand specific SYBR ${ }^{\circledR}$ Green system (Applied Biosystems, \#4367659), TNF- $\alpha$ (Fwd: 5'-TAG CTC CCA GAA AAG CAA GC-3' ; Rev: 5'-TTT TCT GGA GGG AGA TGT GG-3') and 18S (Fwd: 5'-CGC CGC TAG AGG TGA AAT TC-3'; Rev: 5'-TTG GCA AAT GCT TTC GCT C-3') primers and the CFX384 Touch ${ }^{\text {TM }}$ Real-Time PCR Detection System 
(Bio-Rad). Each measurement was performed in triplicate. The relative gene expression was normalized against the $18 \mathrm{~S}$ gene expression. The PBS-treated mice served as reference for mRNA expression (control mRNA level was arbitrarily set at 1).

\section{Protein extraction and western blotting}

Mouse liver specimens were lysed in RIPA buffer (50 mM Tris- $\mathrm{HCl}$ pH 7.4; 1 \% Triton X-100; 25 mM HEPES; 150 mM NaCl; 0,2 \% SDS; 5 mM MgCl 2 ), complemented with $1 \mathrm{mM} \mathrm{Na}_{3} \mathrm{VO}_{4} ; 1 \mathrm{mM} \mathrm{NaF}$ and proteases inhibitors (Roche, \#04 693132 001), using UltraTurax. For protein extraction from primary hepatocytes, cell cultures were lysed with RIPA complemented with proteases and phosphatases inhibitors one day after seeding. After $40 \mathrm{~min}$ in ice, samples were centrifuged at $13,000 \mathrm{~g}$. Proteins from supernatant were assayed with the Bradford method (BioRad) and then separated by SDS-PAGE and transferred onto nitrocellulose membrane. Membranes were blocked with non-fat milk or BSA 3-5 \% in TBS (20 mM Tris, $137 \mathrm{mM} \mathrm{NaCl}$ ) during 1-2 $\mathrm{h}$ and incubated overnight with primary antibody anti-cleaved Caspase-3 (Cell Signaling 9661S), anti-actin (Sigma A3854), anti- TNF-a (Abcam, ab6671) or anti-RIPK1 (Cell Signaling, 3493) at $4^{\circ} \mathrm{C}$, and then with secondary goat anti-rabbit immunoglobulins/HRP antibody (Dako, P0448). Protein-antibody complexes were revealed by enhanced chemiluminescence (Millipore) and ImageQuant LAS-4000 mini imager analysis (GE-Healthcare).

\section{Serum cytokine immunoassay by flow cytometry}


Murine TNF- $\alpha$, IL-6 and MIP-1 $\alpha /$ CCL3 cytokines were quantified by bead-based immunoassays according to manufacturer protocol, using a filter plate and a vacuum filtration system for washing steps (BioLegend's LEGENDPLEX, multi-analyte flow assay kit). Samples were analyzed on a LSR Fortessa cytometer (BD Biosciences).

\section{Statistical analysis}

Data were expressed as means $+/$ - SEM for all mice treated similarly. Kruskal-Wallis one-way analysis of variance (ANOVA) was performed, and mean differences between experimental groups were assessed using the non-parametric MannWhitney U-test with the GraphPad Prism5 software. The significance is shown as follows: * $p<0.05,{ }^{\star *} p<0.01,{ }^{\star \star \star} p<0.001$, Ripk1fl/fl mice versus Ripk1 ${ }^{\text {LPC-KO }}$ mice. \# $p<0.05, \# \# p<0.01, \# \# \#<<0.001$, mice treated with LPS or CpG-DNA versus mice treated with PBS.

\section{RESULTS}

Deficiency of RIPK1 in liver parenchymal cells sensitizes to liver damage induced by PAMPs

To investigate the role of RIPK1 in the liver, we used the Ripk1 $1^{\text {LPC-KO }}$ strain mice which presented a specific deletion of RIPK1 in liver parenchymal cells (Supplementary Figure 1). As described previously [24], these mice, as well as their $R i p k 1^{f / f l}$ littermates are viable in adulthood and displayed normal serum transaminases levels suggested that deficiency of RIPK1 in steady state does not induce hepatolysis (Fig. 1A). Next, we evaluated acute effects on the liver of CpG- 
DNA or LPS administration in Ripk1 $1^{f / f t l}$ and Ripk1 $1^{\text {LPC-KO }}$ mice by monitoring serum levels of ALT and AST, as well as liver histology by H\&E and TUNEL staining. Whereas Ripk1 $1^{f / f t}$ mice did not exhibit increase in serum transaminase levels, sera from Ripk1 $1^{\text {LPC-KO }}$ mice revealed significant increase of ALT and AST after administration of CpG-DNA and severe hepatolysis after low dose of LPS $(0.4 \mu \mathrm{g} / 20$ g of body weight) injection (Fig. 1A). In line with these results, liver sections of Ripk1 $1^{f / f l}$ showed unaffected structures, while tissue damages, revealed by HES coloration, and associated with TUNEL positive cells and cleaved caspase-3 (Clcaspase 3) staining, a marker of apoptosis induction, were observed in liver sections from Ripk $1^{\text {LPC-KO }}$ mice exposed to CpG-DNA (Fig. 1B). These were even more significant in Ripk1 ${ }^{\text {LPC-KO }}$ mice subjected to LPS administration (Fig 1C).

In order to evaluate whether RIPK1 deficiency had any impact on the systemic inflammatory response, we measured the levels of serum pro-inflammatory cytokines in CpG-DNA or LPS injected mice. Administration of CpG-DNA triggered a quick release (1.5 h pi) of TNF- $\alpha$ and IL-6. Whereas TNF- $\alpha$ returned at its basal level $8.5 \mathrm{~h}$ post-injection, serum IL-6 quantities remained high. However, no difference was observed between Ripk1 $1^{f / f t}$ and Ripk1 $1^{L P C-K O}$ mice (Fig. 2A). We next evaluated the same cytokines but also the chemokines MCP1/CCL2 and MIP-1a/CCL3 in sera from LPS injected mice. Interestingly, absence of RIPK1 did not affect the early (1.5 h p.i.) release of IL-6, CCL2 and CCL3 but weakly increased serum TNF-a levels, and led to a significant sustained expression of TNF- $\alpha, C C L 2$ and MIP-1 $\alpha / C C L 3$ at the time of apoptosis induction (8.5 h p.i.) (Fig. 2B). In the same manner, PAMPs injection triggered TNF- $\alpha, C C L 2$ and CCL3 liver transcription. However, Ripk ${ }^{L P C-K O}$ mice more expressed these cytokines $8.5 \mathrm{~h}$ after PAMPs administration which correlated with liver damage (Supplementary figure 2). Moreover, H\&E coloration and 
myeloperoxidase (MPO) labelling of liver sections showed higher infiltrations of inflammatory cells in Ripk1 $1^{\text {LPC-KO }}$ mice after LPS administration (Fig 1B-1C and Fig 2C). Thus, whereas CpG-DNA triggered a moderate hepatolysis associated with low inflammation, LPS administration induced severe acute hepatocyte death which were associated with more extended pro-inflammatory cytokine expression and more important recruitment of inflammatory cells when RIPK1 were absent in liver parenchymal cells. Thus, to better understand the protective role of RIPK1 during hepatitis induced by PAMPs administration, we continued experiments with the LPS model.

\section{Depletion of Kupffer cells reduces LPS-mediated hepatitis in Ripk $1^{\text {LPC-KO }}$ mice}

Kupffer cells are widely involved in LPS-mediated inflammation [8]. In order to evaluate their contribution to the severe liver damage induced by LPS in Ripk1 ${ }^{\text {LPC-KO }}$ mice, we specifically depleted mice from their macrophages by treating them for two days with liposome-encapsulated $\mathrm{Cl}_{2} \mathrm{MBP}$ ( $\mathrm{Lip}-\mathrm{Cl}_{2} \mathrm{MBP}$ ) [26]. In order to confirm macrophage depletion, including in the hepatic tissue, liver sections were stained with anti-F4/80, a well-known marker of murine macrophage population [27]. While abundant F4/80 positive cells were detected in the liver of sham Ripk1 $1^{\text {LPC-KO }}$ mice (LPS challenged controls pretreated with vehicle [PBS] in place of Lip- $\mathrm{Cl}_{2} \mathrm{MBP}$ ), the labelling was dramatically reduced in the liver of LPS-challenged animals pretreated with Lip-Cl ${ }_{2} \mathrm{MBP}$ (Supplementary figure $3 \mathrm{~A}$ ). This proved the effectiveness of our pretreatment. Accordingly, the early LPS-mediated increased in serum levels of CCL3 and IL-6, two cytokines mainly produced by macrophages, were significantly reduced in mice pretreated with $\mathrm{Lip}-\mathrm{Cl}_{2} \mathrm{MBP}$ (Supplementary figure 3B). Interestingly, macrophage depletion greatly rescued the liver damage induced by LPS in Ripk1 ${ }^{\text {LPC- }}$ 
${ }^{K O}$ mice. Indeed, Lip- $\mathrm{Cl}_{2} \mathrm{MBP}$ pre-treatment massively reduced LPS-induced serum transaminase levels (Fig. 3A), which was associated with a reduction of necrosis areas, of TUNEL positive cells as well as of apoptotic cells (Fig. 3B and 3C).

TNF- $\alpha$ produced by Kupffer cells mediates LPS-induced liver damage in Ripk1 $^{\text {LPC-KO }}$ mice

Our results demonstrated a key role of Kupffer cells during LPS-mediated liver injury in Ripk1 $1^{L P C-K O}$ mice. Macrophages are the main source of the TNF- $\alpha$ produced in the body and RIPK1 deficient cells such as embryonic fibroblasts, thymocytes or keratinocytes [28] [29], as well as intestinal organoids [23] have been reported to be sensitized to TNF- $\alpha$-mediated apoptosis. We therefore speculated that TNF- $\alpha$, known to be mainly produced by Kupffer cells in response to LPS sensing [30] [31], was responsible for the apoptotic death of the RIPK1 deficient hepatocytes. In accordance with this idea, we found that TNF- $\alpha$ was quickly released in Ripk1 $1^{\text {LPC-KO }}$ and Ripk1fl/fl littermates following LPS injection (Fig. 2B), and that depletion of macrophages reduced by more than $90 \%$ the serum concentration of TNF- $\alpha, 1.5 \mathrm{~h}$ after LPS administration in Ripk1 $1^{\mathrm{LPC}-\mathrm{KO}}$ mice (Fig. 4A). Moreover isolation of F4/80 positive cells from Ripk1 $1^{f / f f l}$ and Ripk1 ${ }^{L P C-K O}$ mice, $1.5 \mathrm{~h}$ after PBS or LPS treatment showed that LPS induced an upregulation of the TNF- $\alpha$ mRNA in these cells, at similar levels in both mouse strains (Fig. 4B). In addition, cellular staining of TNF- $\alpha$ and F4/80 on liver sections of Ripk1 $1^{L P C-K O}$ mice pre-treated or not with $L i p-\mathrm{Cl}_{2} \mathrm{MBP}$ demonstrated that liver macrophages are the major source of TNF- $\alpha$ produced in the liver after LPS challenge (Fig. 4C, orange arrows). Some single TNF positive cells with no F4/80 labelling were detected. They may correspond to F4/80 negative cells, 
such as sinusoidal liver cells, able to produce TNF at lesser extend (Fig. 4B, white arrows).

As we demonstrated that macrophage depletion in Ripk $1^{L P C-K O}$ mice prevented from both a TNF- $\alpha$ burst and severe liver damages, we investigated the role of TNF- $\alpha$ in our model by pre-treating Ripk $1^{L P C-K O}$ mice for $1 \mathrm{~h}$ with Etanercept, a TNF- $\alpha$ decoy receptor widely used clinically in humans, before LPS injection. Remarkably, we found that TNF-a blockade fully protected Ripk $1^{\text {LPC-KO }}$ mice from LPS-induced liver injury, as demonstrated by the dramatic reduction of serum transaminase levels (Fig. $5 \mathrm{~A})$, the absence of necrotic areas, and the reduction of TUNEL and Cl-caspase 3 positive cells in the livers of Ripk $1^{L P C-K O}$ mice (Fig. 5B). Western blot analysis confirmed the presence of TNF- $\alpha$ release and Caspase 3 activation in the livers of $R_{i p k} 1^{f / f l}$ and Ripk1 ${ }^{\text {LPC-KO }}$ mice after LPS injection, which were avoided by the Etanercept pre-treatment (Fig. 5C).

\section{DISCUSSION}

Hepatocyte death is a key trigger of liver disease progression [32]. During chronic hepatitis, acute hepatocyte death can occur and causes ACLF, and induces quick and high mortality rate in patients [7]. One of its main cause is the elevation of gutderived-microbacterial products in the liver [6]. PAMPs activate TLR receptors, expressed at the surface of innate immune cells, such as KC, inducing cytokine release which promotes liver inflammation and hepatocyte death, eventually leading to liver failure [8]. Elevation of bacterial products in the liver can be mimic by LPS or CpG-DNA injection in mice. In healthy liver, their administration induces a quick delivery of cytokines without triggering liver injury. However, during ACLF, 
inflammatory context of chronic hepatitis sensitizes hepatocytes, and elevation of PAMPs in the liver triggers acute hepatocyte death and liver failure [9] [5] [10] [11]. In many studies, treatment with D-GalN was used to investigate endotoxin mediated liver injury. D-GalN leads to uridine depletion that sensitizes hepatocyte to LPSinduced apoptosis by inhibiting survival proteins transcription [17]. Here, we showed that in Ripk $1^{L P C-K O}$ mice, administration of LPS or CpG-DNA, without adding D-GalN, was sufficient to induce strong acute liver injury associated with hepatocyte apoptosis. Previously, an identical phenotype was observed in conditional or inducible LPC-KO mice for NEMO, TAK1 or RelA [33] [34] [19]. However, whereas these mice presented hepatolysis at steady state, RIPK1 seems dispensable for liver homeostasis as we and others previously showed that Ripk1 $1^{\text {LPC-KO }}$ adult mice are viable and do not present abnormal hepatocyte death or proliferation [33] [24]. LPS injection induced a quick release of cytokines in bloodstream that was poorly or not affected by RIPK1 deficiency in LPC. However, whereas at latter time, serum cytokine levels were almost back to their basal levels in Ripk1/flft mice, their Ripk1 ${ }^{\text {LPC- }}$ ${ }^{K O}$ littermates presented a sustained inflammation associated with inflammatory cells infiltration. This possibly resulted from the release of damage associated molecular pattern (DAMPs) issued from dead hepatocytes. As KC are important source of cytokine delivery after LPS administration, and as it has been observed that PAMP recognition by $\mathrm{KC}$ is a key step in the induction of liver injury during chronic alcoholic, NASH or acute hepatitis induced by D-GalN in mice [35] [36] [37] [10] [38], we next investigated the role of $K C$ in LPS-mediated liver damage in Ripk1 $1^{L P C-K O}$ mice. Liposome-encapsulated $\mathrm{Cl}_{2} \mathrm{MBP}$ is an efficient method to deplete macrophages and to study the role of cytokines induced by LPS stimulation [26]. Indeed, in contrast to other methods (such as gadolinium chloride, silica or dextran sulfate), liposomes do 
not stimulate production of cytokines by macrophages [26]. Depletion of KC in the liver was associated with a strong reduction of hepatolysis in Ripk $1^{L P C-K O}$ mice challenged with LPS. Whereas RIPK1 has been shown to regulate TLR signaling [39], our data revealed an indirect role of LPS to induce hepatocyte death in $R_{i p k 1^{L P C-K O}}$ mice. Thus, we suggest that, in Ripk1 $1^{\text {LPC-KO }}$ mice, LPS activated TLR4, mainly present on $\mathrm{KC}$, which induced the release of cytokines deleterious for hepatocytes. In accordance with others, we found an important reduction of serum TNF- $\alpha$ level after LPS challenge in mice previously depleted from their macrophages [30] [31], suggesting a deleterious role of TNF- $\alpha$ in Ripk $1^{\text {LPC-KO }}$ mice. Moreover TNF- $\alpha$ release by LPS-activated $\mathrm{KC}$ has been shown to play a key role during acute and chronic liver diseases in different mice models, where it was shown to promote fibrosis and hepatolysis [15] [16] [40]. In the same way, we showed that TNF-a inhibition with Etanercept fully protected hepatocytes from the apoptosis induced by LPS in Ripk1 ${ }^{\text {LPC-KO }}$. The low hepatolysis observed after LPS treatment in Ripk1 ${ }^{\text {LPC-KO }}$ mice previously depleted from their macrophages can be probably attributed to the small detected quantities of TNF- $\alpha$, which may originate from the few surviving macrophages which escaped from Lip- $\mathrm{Cl}_{2} \mathrm{MBP}$ pretreatment, and/or from other liver cells.

Previously, we showed that RIPK1 plays a key protective role in murine hepatocytes when TNF signaling is triggered by concanavalin $A$, a model of T-cells induced hepatitis [24] (see extended discussion). These supported our herein data showing that physiological production of TNF- $\alpha$ by LPS-activated KC led to hepatocyte apoptosis in Ripk1 $1^{\text {LPC-KO }}$ mice. The role of soluble and transmembrane TNF- $\alpha$ in LPSmediated hepatitis is currently discussed [41, 42]. As Etanercept blocks both forms [43], we cannot distinguish the more active one in our experiments. However, 
although no conclusions can be drawn from our experimental model on tm-TNF involvement, we can conclude that its soluble form was sufficient to promote liver injury. Indeed, LPS triggered high release of soluble TNF- $\alpha$ in the bloodstream and single soluble recombinant TNF- $\alpha$ injection is able alone to trigger acute hepatocyte apoptosis in RipK1 $1^{\text {LPC-KO }}$ mice [24]. TNF- $\alpha$ can generate intracellular signaling through interaction either with TNFR1 or with TNFR2. However, TNFR1 seems to play a predominant role in the liver [44]. Thus, in the TNF-a/D-GalN hepatitis model, the deficiency of TNFR1 in liver parenchymal cells is sufficient to fully protect animals against liver damages [45]. Taking into account the different aspects discussed above, we proposed a schematic model on the vital role played by RIPK1 to maintain liver homeostasis under elevated PAMPs conditions (Fig. 6).

In conclusion, the sensitivity of Ripk $1^{L P C-K O}$ mice to PAMPs such as LPS and CpGDNA, could be used as a model to test some TLR inhibitors or probiotics and antibiotics which are currently investigated to reduce inflammatory response induced by high bacterial translocation in the liver [5]. Moreover, this sensitivity of RIPK1 ${ }^{L P C-K O}$ mice to PAMPs highlights the importance of the preservation of the RIPK1 function to maintain the liver homeostasis in pathological condition. Thus, analysis of Ripk1 gene polymorphism or RIPK1 expression could be helpful in the management of patients with chronic hepatitis and in the prediction of their risk to develop ACLF.

\section{Acknowledgements}

This work was supported by INSERM, The "Ministère de l'Education Nationale de la Recherche et de la Technologie", the University of Rennes 1, the "Région Bretagne" and the "Ligue contre le cancer", "comités du grand Ouest", the Institut National du 
Cancer" (INCa) and the Contrat de Projet Etat Région «Infectio ». Research in the Vandenabeele group is supported by Belgian grants (Interuniversity Attraction Poles, IAP 7/32), Flemish grants (Research Foundation Flanders: FWO G.0875.11, FWO G.0973.11, FWO G.0A45.12N, FWO G.0787.13N, FWO G.0C31.14N, FWO G0137.15N, FWO G0E04.16N), Methusalem grant - BOF09/01M00709 and BOF16/MET_V/007, Ghent University grants (MRP, GROUP-ID consortium), grant from the 'Foundation against Cancer, 2012-188) and grants from VIB. FWO G0E04.16N), Methusalem grant - BOF16/MET_V/007, Ghent University grants (MRP, GROUP-ID consortium), grant from the 'Foundation against Cancer, 2012188) and grants from VIB. AF was supported by a PhD fellowship from the Région Bretagne. MF was supported by a Ph.D. fellowship from the Government of Pakistan (Higher Education Commission, University of Agriculture, Lahore). MJMB has a tenure track position within the Multidisciplinary Research Program of Ghent University (GROUP-ID). For immunohistochemistry analysis and animal house facilities, we would like to thank dedicated platforms (i.e. H2P2 and animal house platforms) of SFR BIOSIT, University of Rennes 1, France. For experimental help, we would like to thank the student Cristina Ulecia Morón.

\section{LEGENDS OF FIGURES}

Figure 1. RIPK1 deficiency sensitized mice to unmethylated CpG-DNA and LPS PAMPs.

(A) Levels of serum ALT and AST in Ripk1 $1^{\text {fl/fl }}$ and Ripk1 ${ }^{\text {LPC-KO }}$ mice, $8.5 \mathrm{~h}$ after PBS $(n=4-6)$, CpG-DNA ( $n=5-7)$ or LPS $(n=13-15)$ injection (each dot represents an individual and errors bars are expressed as means +/- SEM). Statistical analysis of 
the data was performed by using the non-parametric Mann-Whitney U-test. ${ }^{*}$, \# $p<0.05 ;{ }^{\star *}, \# \# p<0.01 ;{ }^{\star \star *}, \# \# \# p<0.001$, ns: non-significant). (B) and (C) Pictures of liver tissue sections, stained by H\&E (left panels), analyzed by TUNEL (in red) and DAPI (in blue) immunofluorescence (middle panels) or analyzed by IHC for cleaved caspase-3 (right panels), issued from Ripk1 $1^{f / f l}$ or Ripk1 ${ }^{L P C-K O}$ mice, $8.5 \mathrm{~h}$ after CpGDNA or LPS challenge.

Figure 2. RIPK1 deficiency promoted inflammation during PAMPs-induced hepatitis.

(A) Levels of serum TNF- $\alpha$ and IL-6 from Ripk $1^{\text {fl/fl }}$ and Ripk $1^{\text {LPC-KO }}$ mice, $1.5 \mathrm{~h}$ or 8.5 h after PBS or CpG-DNA injection. (B) Levels of serum TNF- $\alpha$, IL-6, MCP1/CCL2 and MIP-1a/CCL3 from Ripk1 $1^{f / f l}$ and Ripk1 $1^{\text {LPC-KO }}$ mice, $1.5 \mathrm{~h}$ or $8.5 \mathrm{~h}$ after PBS or LPS injection. Dotted lines represent the detection threshold. Italic numbers indicate the mice number for each condition, errors bars are expressed as means +/- SEM. Statistical analysis of the data was performed by using the non-parametric MannWhitney U-test. ( ${ }^{\star}, \# \mathrm{p}<0.05 ;{ }^{\star \star}, \# \# \mathrm{p}<0.01 ;{ }^{\star \star \star}, \# \# \mathrm{p}<0.001$, ns: non-significant). (C) Pictures of liver tissue sections analyzed by IHC for myeloperoxidase (MPO) issued from Ripk $1^{\text {fl/fl }}$ or Ripk1 $1^{\text {LPC-KO }}$ mice, $8.5 \mathrm{~h}$ after LPS challenge.

Figure 3. Depletion of Kupffer cells reduced LPS mediated hepatitis in Ripk1 ${ }^{\text {LPC- }}$ Ko mice.

(A) of AST and ALT, collected $8.5 \mathrm{~h}$ after LPS injection in Ripk1 $1^{\text {LPC-KO }}$ mice pretreated $(n=3)$ or not $(n=9)$ with Lip-Cl ${ }_{2}$ MBP. (B) Pictures of liver tissue sections, stained by H\&E (upper panels), analyzed by TUNEL (dead cells in red) and DAPI 
(nuclei in blue) immunofluorescence (middle panels) or analyzed by IHC for cleaved caspase-3 (lower panels), issued from Ripk1 ${ }^{\text {LPC-KO }}$ mice, $8.5 \mathrm{~h}$ after LPS injection with an eventual pre-treatment with Lip- $\mathrm{Cl}_{2} \mathrm{MBP}$. (C) Western-blot analysis of $\beta$-actin and cleaved-caspase 3 in protein extracts issued from the liver of Ripk1/fffl or Ripk1 $1^{\text {LPC-KO }}$ mice, collected $8.5 \mathrm{~h}$ after LPS injection with an eventual pre-treatment with Lip- $\mathrm{Cl}_{2} \mathrm{MBP}$. The 3 lanes for each conditions, represent 3 different mice. On dot plots, each dot represents an individual and errors bars are expressed as means +/SEM. Statistical analysis of the data was performed by using the non-parametric Mann-Whitney U-test. $\left({ }^{*} p<0.05 ;{ }^{* \star} p<0.01 ;{ }^{\star \star *} p<0.001\right)$.

Figure 4. Kupffer cells induced LPS mediated liver damage in RIPK1 mice in a TNF-dependent manner.

(A) Serum levels of TNF- $\alpha$ collected $1.5 \mathrm{~h}$ after LPS injection in Ripk $1^{\text {LPC-KO }}$ mice pretreated or not with Lip-Cl $\mathrm{Cl}_{2} \mathrm{MBP}$, each dot represents an individual (n=3-5). (B) TNF- $\alpha$ transcripts of F4/80 positive cells isolated from Ripk1 $1^{f / f l}$ or Ripk1 $1^{\text {LPC-KO }}$ mice, $1.5 \mathrm{~h}$ after PBS ( $n=2)$ or LPS injection $(n=3-5)$. (C) TNF- $\alpha$ (red) and F4/80 (green) immunofluorescence staining on liver sections from Ripk1 ${ }^{L P C-K O}$ mice, sacrificed $8.5 \mathrm{~h}$

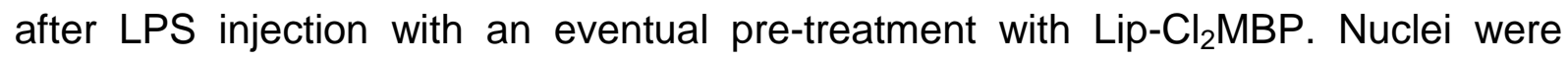
stained by Hoechst (blue). White and orange arrows show TNF positive cells, and TNF and F4/80 positive cells, respectively. Statistical analysis of the data was performed by using the non-parametric Mann-Whitney U-test. Errors bars are expressed as means +/- SEM. ( ${ }^{*} p<0.05 ;{ }^{* *} p<0.01 ;{ }^{* *} p<0.001$, ns: non-significant).

Figure 5. LPS induced TNF-mediated liver damages in Ripk1 $1^{\text {LPC-KO }}$ mice. 
(A) Levels of serum ALT and AST and (B) pictures of liver tissue sections, stained by H\&E (left panels), analyzed by TUNEL (dead cells in red) and DAPI (nuclei in blue) immunofluorescence (middle panels), or analyzed by IHC for cleaved caspase-3 (right panels), issued from Ripk1 $1^{\mathrm{LPC}-K O}$ mice, $8.5 \mathrm{~h}$ after PBS or LPS injection with an eventual pre-treatment with Etanercept $(E T A)(n=6-10)$. On dot plots, each dot represents an individual and errors bars are expressed as means +/- SEM. Statistical analysis of the data was performed by using the non-parametric Mann-Whitney Utest. ( ${ }^{\star}, \# p<0.05 ;{ }^{\star *}, \# \# p<0.01 ;{ }^{\star \star \star}, \# \# \mathrm{p}<0.001$, ns: non-significant). (C) Westernblot analysis of RIPK1, $\beta$-actin, transmembrane (tm) and soluble (s) forms of TNF- $\alpha$ and cleaved-caspase 3 in protein extracts issued from the liver of Ripk ${ }^{t / f t}$ or Ripk1 $1^{\text {LPC-KO }}$ mice, sacrificed $8.5 \mathrm{~h}$ after LPS injection with an eventual pre-treatment with ETA.

\section{Figure 6. Role of RIPK1 in PAMPs mediated hepatitis.}

During some chronic liver diseases, such as acute on chronic liver failure, different factors such as gut permeabilization induce elevated PAMPs translocation in the liver. LPS and CpG-DNA are respectively recognized by TLR4 and 9 carried by Kupffer cells (KC) which promotes inflammatory cytokine production such as TNF- $\alpha$. Transmembrane (tm-) or (s-) soluble TNF can be inhibited by Etanercept (ETA), if not, they bind the TNFR1 on hepatocytes and promote recruitment of RIPK1 under the receptor which plays a protective role by preventing caspase activation.

\section{REFERENCES}

[1] Wiest R, Garcia-Tsao G. Bacterial translocation (BT) in cirrhosis. Hepatology 2005;41:422-433. 
[2] Crispe IN. The liver as a lymphoid organ. Annu Rev Immunol 2009;27:147-163.

[3] Louvet A, Mathurin P. Alcoholic liver disease: mechanisms of injury and targeted treatment. Nat Rev Gastroenterol Hepatol 2015;12:231-242.

[4] Ilan Y. Leaky gut and the liver: a role for bacterial translocation in nonalcoholic steatohepatitis. World J Gastroenterol 2012;18:2609-2618.

[5] Mencin A, Kluwe J, Schwabe RF. Toll-like receptors as targets in chronic liver diseases. Gut 2009;58:704-720.

[6] Jalan R, Fernandez J, Wiest R, Schnabl B, Moreau R, Angeli P, et al. Bacterial infections in cirrhosis: a position statement based on the EASL Special Conference 2013. J Hepatol 2014;60:13101324.

[7] Sarin SK, Choudhury A. Acute-on-chronic liver failure: terminology, mechanisms and management. Nat Rev Gastroenterol Hepatol 2016;13:131-149.

[8] Heymann F, Tacke F. Immunology in the liver - from homeostasis to disease. Nat Rev Gastroenterol Hepatol 2016;13:88-110.

[9] Jirillo E, Caccavo D, Magrone T, Piccigallo E, Amati L, Lembo A, et al. The role of the liver in the response to LPS: experimental and clinical findings. J Endotoxin Res 2002;8:319-327.

[10] Rivera CA, Adegboyega P, van Rooijen N, Tagalicud A, Allman M, Wallace M. Toll-like receptor-4 signaling and Kupffer cells play pivotal roles in the pathogenesis of non-alcoholic steatohepatitis. J Hepatol 2007;47:571-579.

[11] Inokuchi S, Tsukamoto H, Park E, Liu ZX, Brenner DA, Seki E. Toll-like receptor 4 mediates alcohol-induced steatohepatitis through bone marrow-derived and endogenous liver cells in mice. Alcohol Clin Exp Res 2011;35:1509-1518.

[12] Trebicka J, Krag A, Gansweid S, Appenrodt B, Schiedermaier P, Sauerbruch T, et al. Endotoxin and tumor necrosis factor-receptor levels in portal and hepatic vein of patients with alcoholic liver cirrhosis receiving elective transjugular intrahepatic portosystemic shunt. Eur J Gastroenterol Hepatol 2011;23:1218-1225.

[13] Spahr L, Giostra E, Frossard JL, Bresson-Hadni S, Rubbia-Brandt L, Hadengue A. Soluble TNFR1, but not tumor necrosis factor alpha, predicts the 3-month mortality in patients with alcoholic hepatitis. J Hepatol 2004;41:229-234.

[14] Galanos C, Freudenberg MA, Reutter W. Galactosamine-induced sensitization to the lethal effects of endotoxin. Proc Natl Acad Sci U S A 1979;76:5939-5943.

[15] Kudo H, Takahara T, Yata Y, Kawai K, Zhang W, Sugiyama T. Lipopolysaccharide triggered TNFalpha-induced hepatocyte apoptosis in a murine non-alcoholic steatohepatitis model. J Hepatol 2009;51:168-175.

[16] Tiegs G, Wolter $M$, Wendel A. Tumor necrosis factor is a terminal mediator in galactosamine/endotoxin-induced hepatitis in mice. Biochem Pharmacol 1989;38:627-631.

[17] Decker K, Keppler D. Galactosamine hepatitis: key role of the nucleotide deficiency period in the pathogenesis of cell injury and cell death. Rev Physiol Biochem Pharmacol 1974:77-106.

[18] Leist M, Gantner F, Bohlinger I, Germann PG, Tiegs G, Wendel A. Murine hepatocyte apoptosis induced in vitro and in vivo by TNF-alpha requires transcriptional arrest. J Immunol 1994;153:1778-1788.

[19] Geisler F, Algul H, Paxian S, Schmid RM. Genetic inactivation of RelA/p65 sensitizes adult mouse hepatocytes to TNF-induced apoptosis in vivo and in vitro. Gastroenterology 2007;132:24892503.

[20] Naveau S, Chollet-Martin S, Dharancy S, Mathurin P, Jouet P, Piquet MA, et al. A doubleblind randomized controlled trial of infliximab associated with prednisolone in acute alcoholic hepatitis. Hepatology 2004;39:1390-1397.

[21] Boetticher NC, Peine CJ, Kwo P, Abrams GA, Patel T, Aqel B, et al. A randomized, doubleblinded, placebo-controlled multicenter trial of etanercept in the treatment of alcoholic hepatitis. Gastroenterology 2008;135:1953-1960.

[22] Pasparakis M, Vandenabeele P. Necroptosis and its role in inflammation. Nature 2015;517:311-320. 
[23] Takahashi N, Vereecke L, Bertrand MJ, Duprez L, Berger SB, Divert T, et al. RIPK1 ensures intestinal homeostasis by protecting the epithelium against apoptosis. Nature 2014;513:95-99.

[24] Filliol A, Piquet-Pellorce C, Le Seyec J, Farooq M, Genet V, Lucas-Clerc C, et al. RIPK1 protects from TNF- $\alpha$ mediated liver damage during hepatitis. Cell Death Dis 2016;7:e2462.

[25] Van Rooijen N, Sanders A. Liposome mediated depletion of macrophages: mechanism of action, preparation of liposomes and applications. J Immunol Methods 1994;174:83-93.

[26] van Rooijen N, Sanders A. Elimination, blocking, and activation of macrophages: three of a kind? J Leukoc Biol 1997;62:702-709.

[27] Austyn JM, Gordon S. F4/80, a monoclonal antibody directed specifically against the mouse macrophage. Eur J Immunol 1981;11:805-815.

[28] Kelliher MA, Grimm S, Ishida Y, Kuo F, Stanger BZ, Leder P. The death domain kinase RIP mediates the TNF-induced NF-kappaB signal. Immunity 1998;8:297-303.

[29] Gentle IE, Wong WW, Evans JM, Bankovacki A, Cook WD, Khan NR, et al. In TNF-stimulated cells, RIPK1 promotes cell survival by stabilizing TRAF2 and CIAP1, which limits induction of noncanonical NF-kappaB and activation of caspase-8. J Biol Chem 2011;286:13282-13291.

[30] Bautista AP, Skrepnik N, Niesman MR, Bagby GJ. Elimination of macrophages by liposomeencapsulated dichloromethylene diphosphonate suppresses the endotoxin-induced priming of Kupffer cells. J Leukoc Biol 1994;55:321-327.

[31] Luster MI, Germolec DR, Yoshida T, Kayama F, Thompson M. Endotoxin-induced cytokine gene expression and excretion in the liver. Hepatology 1994;19:480-488.

[32] Luedde T, Kaplowitz N, Schwabe RF. Cell death and cell death responses in liver disease: mechanisms and clinical relevance. Gastroenterology 2014;147:765-783 e764.

[33] Kondylis V, Polykratis A, Ehlken H, Ochoa-Callejero L, Straub BK, Krishna-Subramanian S, et al. NEMO Prevents Steatohepatitis and Hepatocellular Carcinoma by Inhibiting RIPK1 Kinase ActivityMediated Hepatocyte Apoptosis. Cancer Cell 2015;28:582-598.

[34] Bettermann K, Vucur M, Haybaeck J, Koppe C, Janssen J, Heymann F, et al. TAK1 suppresses a NEMO-dependent but NF-kappaB-independent pathway to liver cancer. Cancer Cell 2010;17:481496.

[35] Adachi E, Maeda T, Matsumata T, Shirabe K, Kinukawa N, Sugimachi K, et al. Risk factors for intrahepatic recurrence in human small hepatocellular carcinoma. Gastroenterology 1995;108:768775.

[36] Ben Ari Z, Avlas O, Pappo O, Zilbermints V, Cheporko Y, Bachmetov L, et al. Reduced hepatic injury in Toll-like receptor 4-deficient mice following D-galactosamine/lipopolysaccharide-induced fulminant hepatic failure. Cell Physiol Biochem 2012;29:41-50.

[37] Spruss A, Kanuri G, Wagnerberger S, Haub S, Bischoff SC, Bergheim I. Toll-like receptor 4 is involved in the development of fructose-induced hepatic steatosis in mice. Hepatology 2009;50:1094-1104.

[38] Uesugi T, Froh M, Arteel GE, Bradford BU, Thurman RG. Toll-like receptor 4 is involved in the mechanism of early alcohol-induced liver injury in mice. Hepatology 2001;34:101-108.

[39] Meylan E, Burns K, Hofmann K, Blancheteau V, Martinon F, Kelliher M, et al. RIP1 is an essential mediator of Toll-like receptor 3-induced NF-kappa B activation. Nat Immunol 2004;5:503507.

[40] Miura K, Yang L, van Rooijen N, Ohnishi H, Seki E. Hepatic recruitment of macrophages promotes nonalcoholic steatohepatitis through CCR2. Am J Physiol Gastrointest Liver Physiol 2012;302:G1310-1321.

[41] Olleros ML, Vesin D, Fotio AL, Santiago-Raber ML, Tauzin S, Szymkowski DE, et al. Soluble TNF, but not membrane TNF, is critical in LPS-induced hepatitis. J Hepatol 2010;53:1059-1068.

[42] Yang P, Zhou W, Li C, Zhang M, Jiang Y, Jiang R, et al. Kupffer-cell-expressed transmembrane TNF-alpha is a major contributor to lipopolysaccharide and D-galactosamine-induced liver injury. Cell Tissue Res 2016;363:371-383.

[43] Tracey D, Klareskog L, Sasso EH, Salfeld JG, Tak PP. Tumor necrosis factor antagonist mechanisms of action: a comprehensive review. Pharmacol Ther 2008;117:244-279. 
[44] Liedtke C, Trautwein C. The role of TNF and Fas dependent signaling in animal models of inflammatory liver injury and liver cancer. Eur J Cell Biol 2012;91:582-589.

[45] Wroblewski R, Armaka M, Kondylis V, Pasparakis M, Walczak H, Mittrucker HW, et al. Opposing role of tumor necrosis factor receptor 1 signaling in $\mathrm{T}$ cell-mediated hepatitis and bacterial infection in mice. Hepatology 2016;64:508-521.

Author names in bold designate shared co-first authorship. 
Figure 1

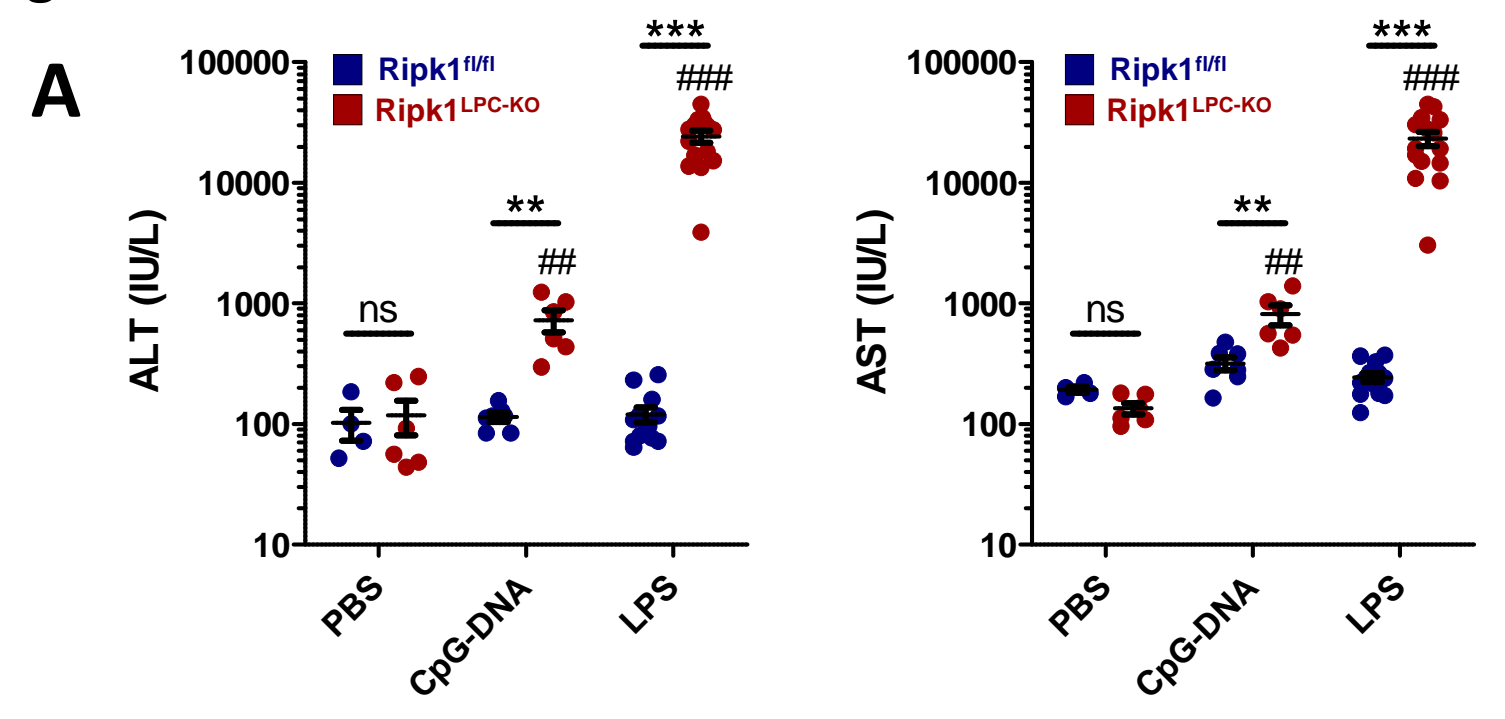

B

CpG-DNA, $8.5 \mathrm{~h}$

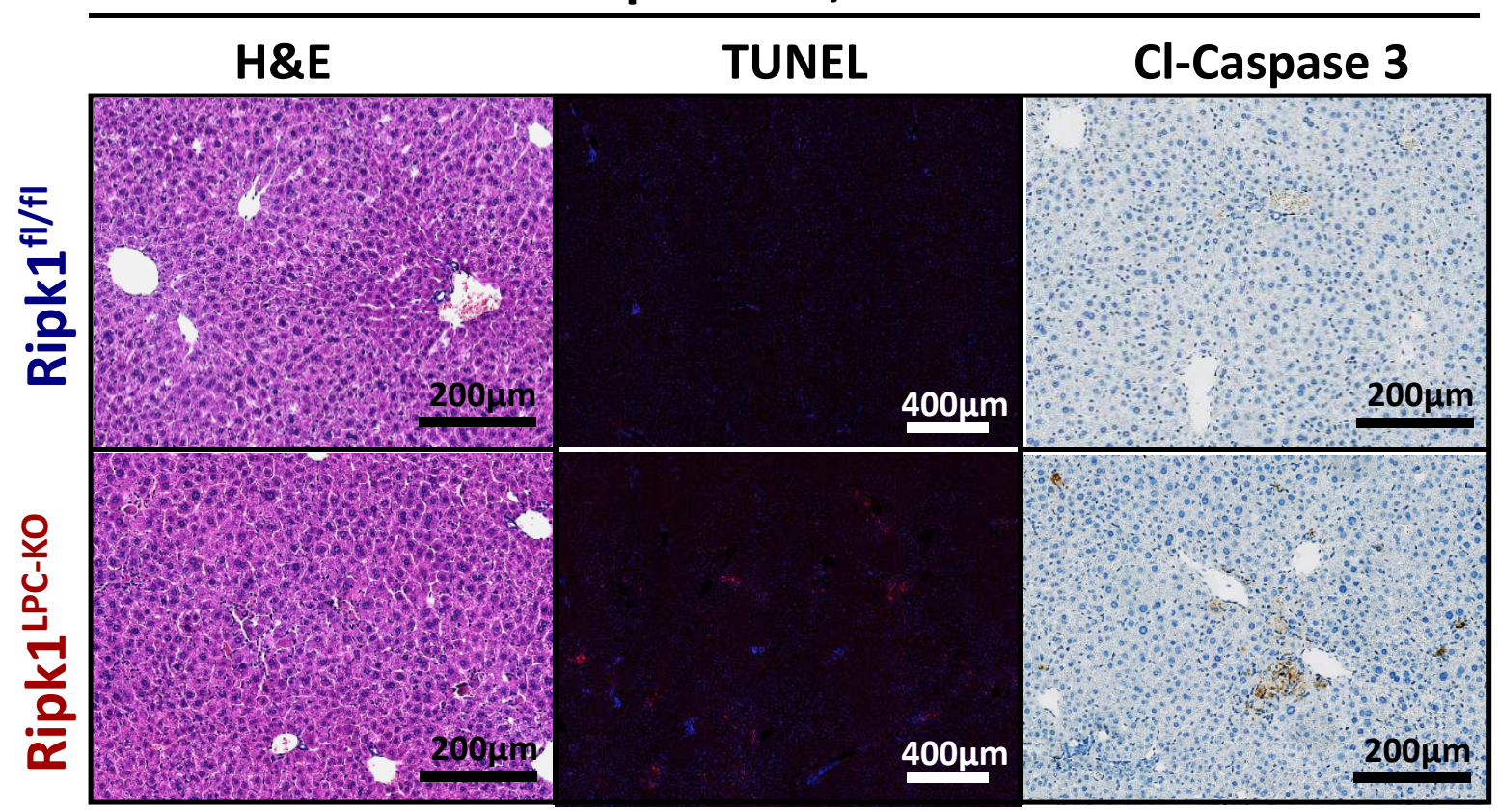

C

LPS, 8.5 h

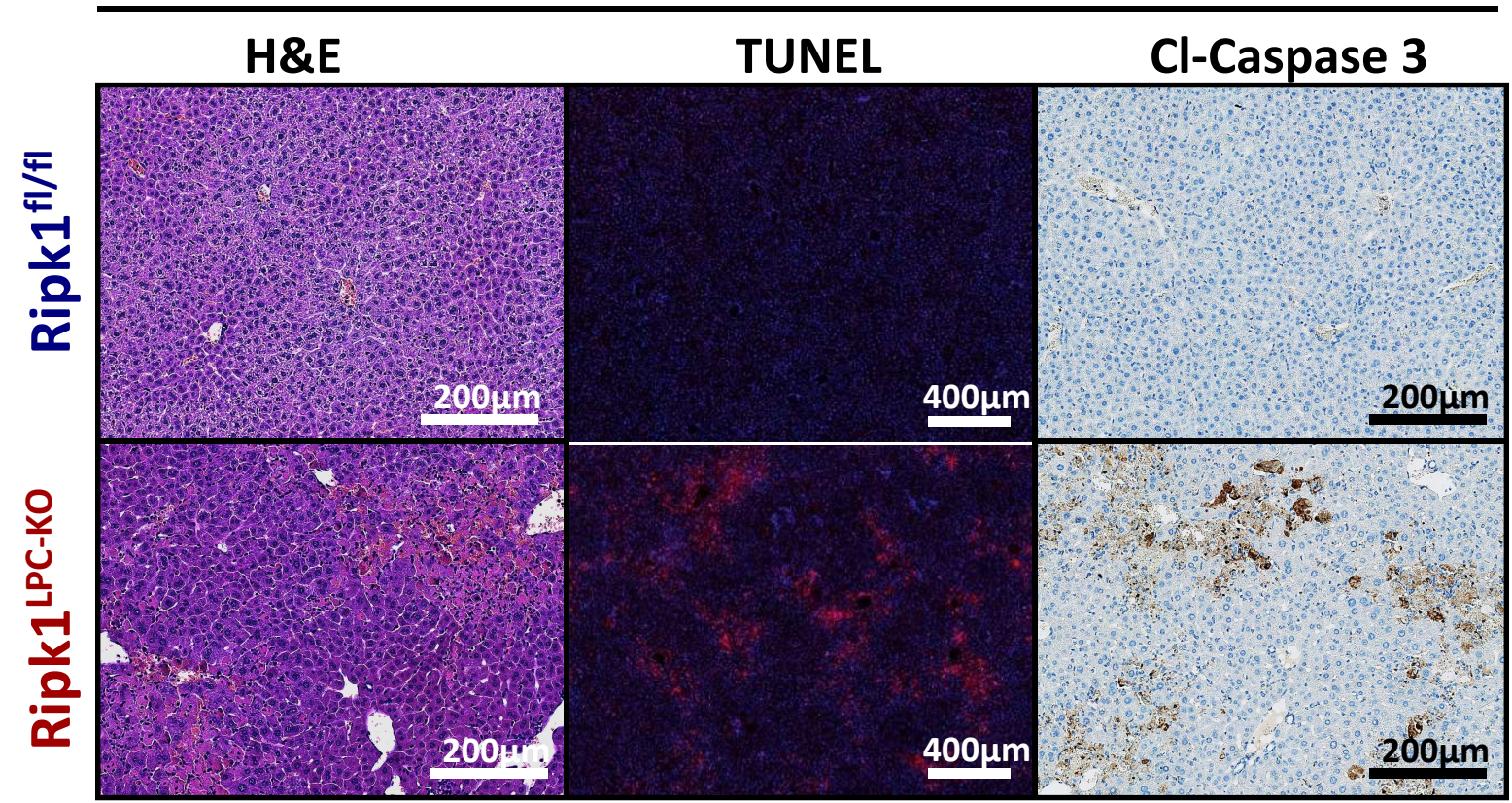




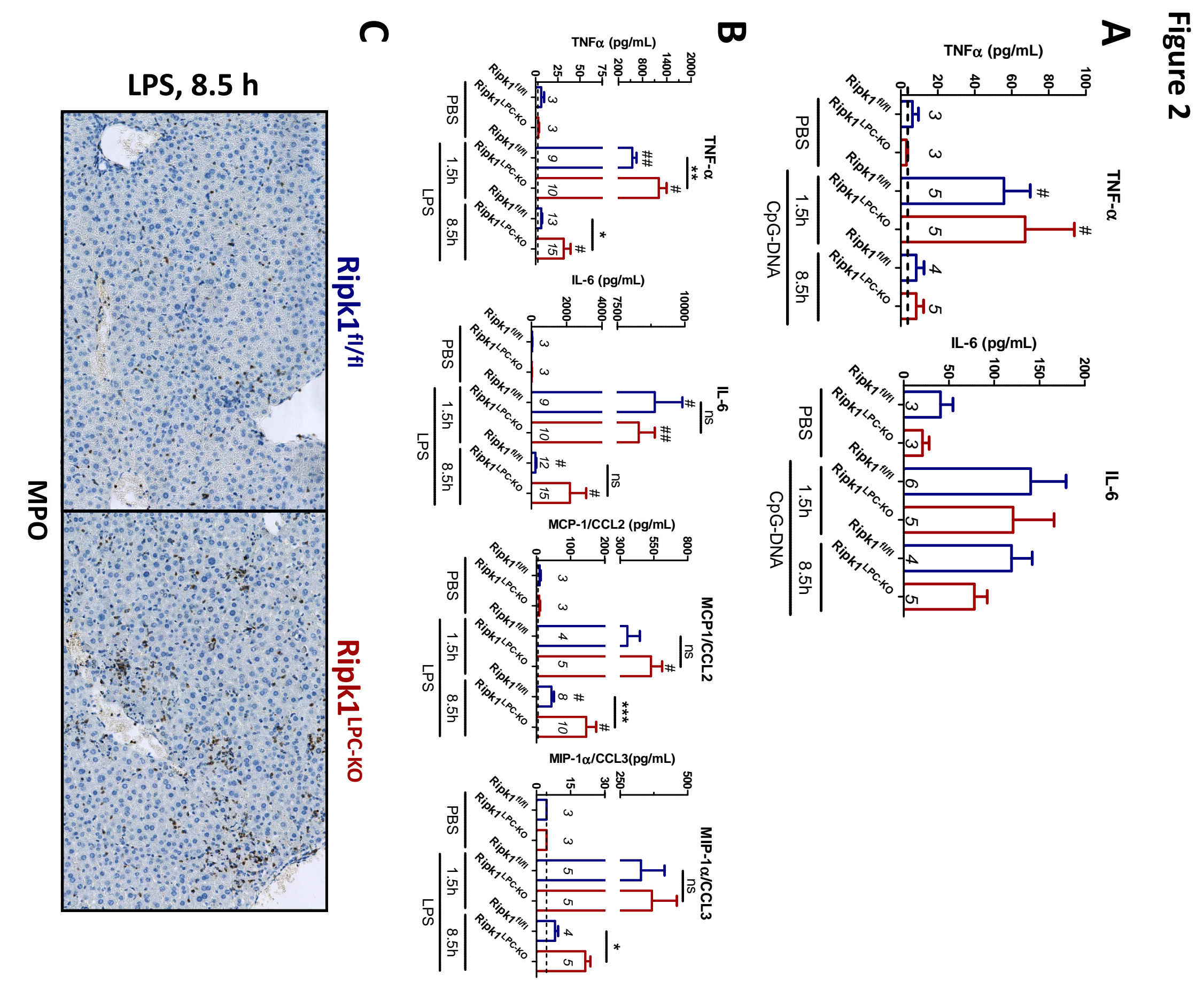


Figure 3

A

ALT

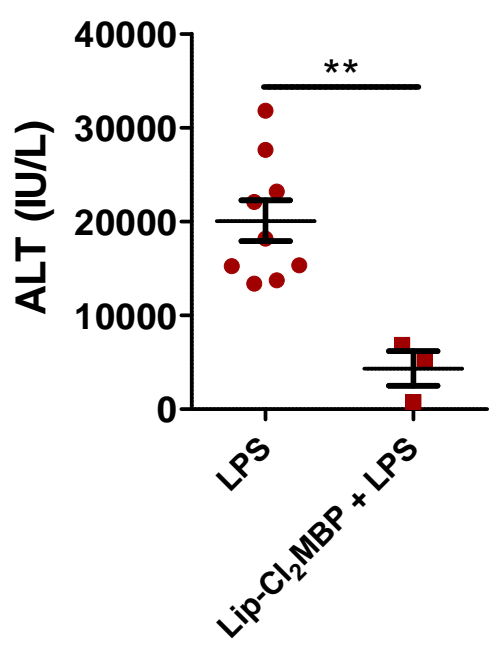

B

LPS Lip-Cl ${ }_{2} M B P+L P S$

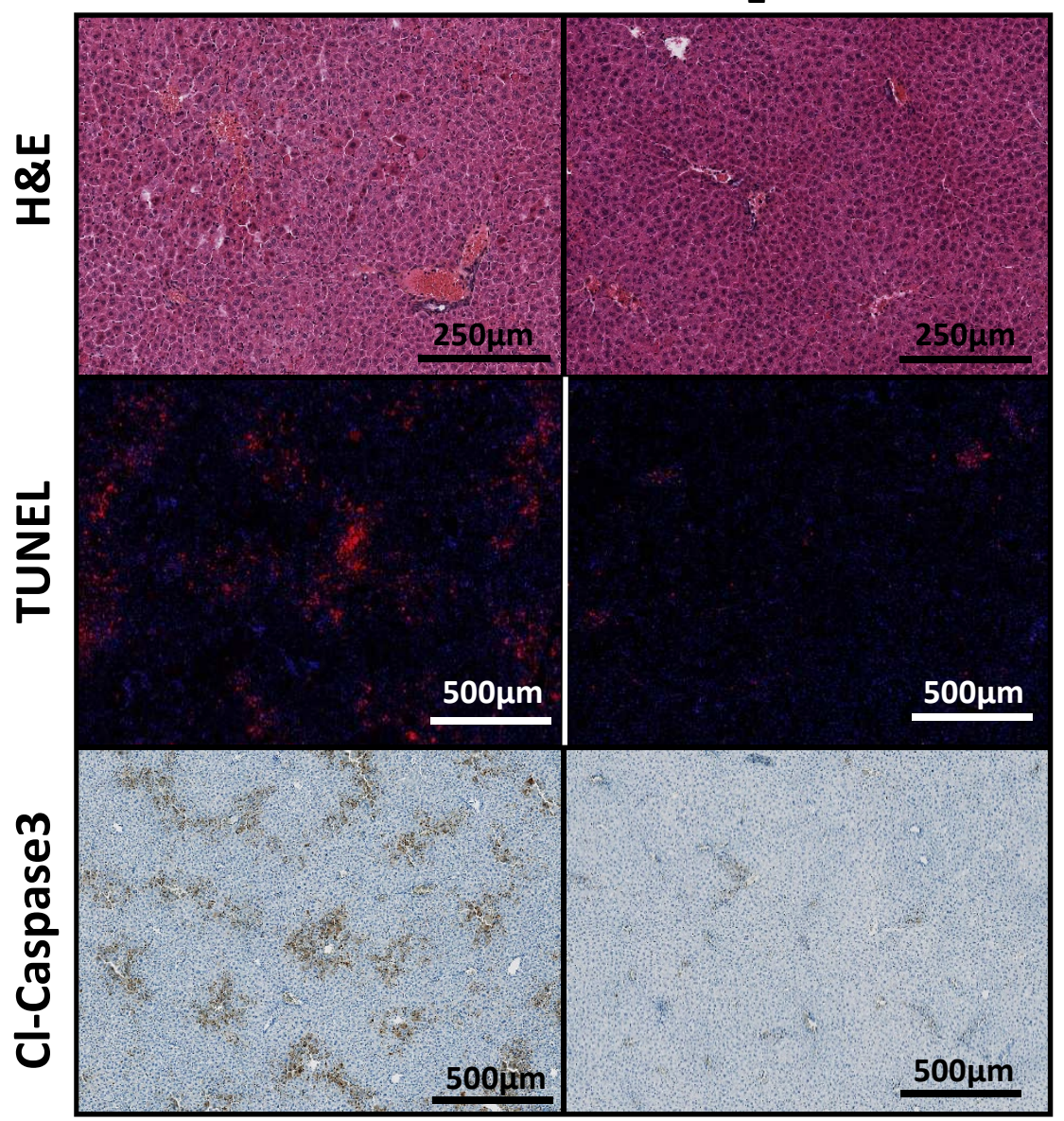

C Ripk1 ${ }^{\text {LPC-KO }}$

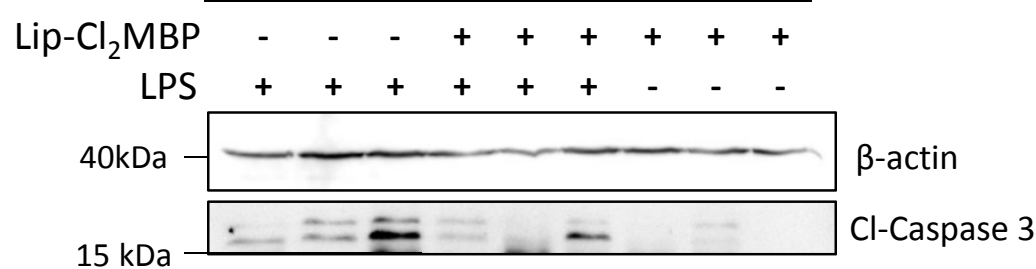


Figure 4

A

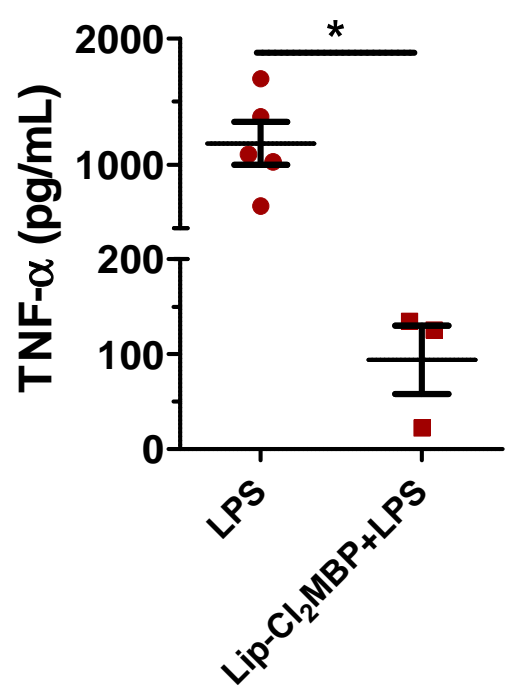

B

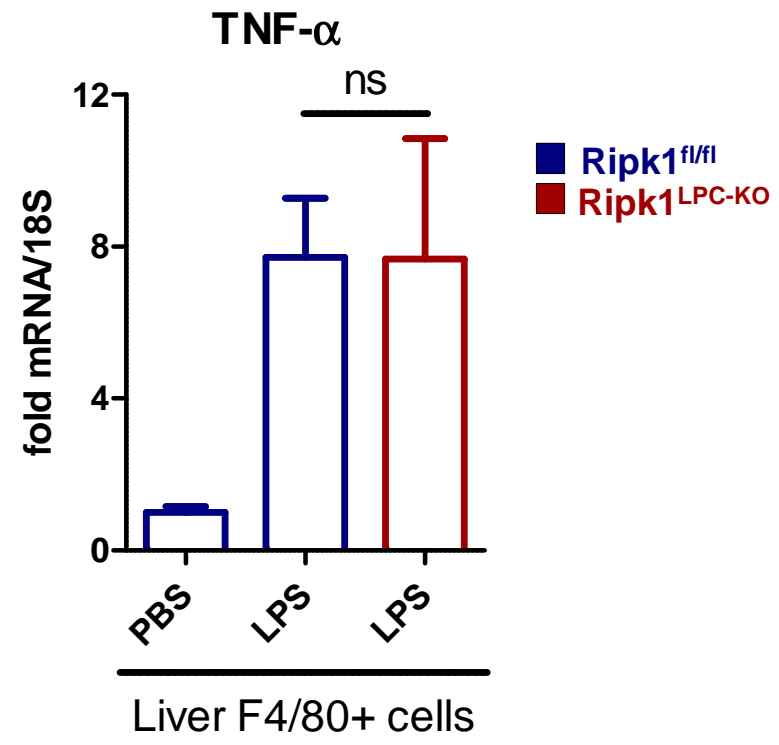

C

Ripk1 $1^{\text {LPC-KO }}$

TNF

$\mathrm{F} 4 / 80$

TNF-F4/80-Hoechst

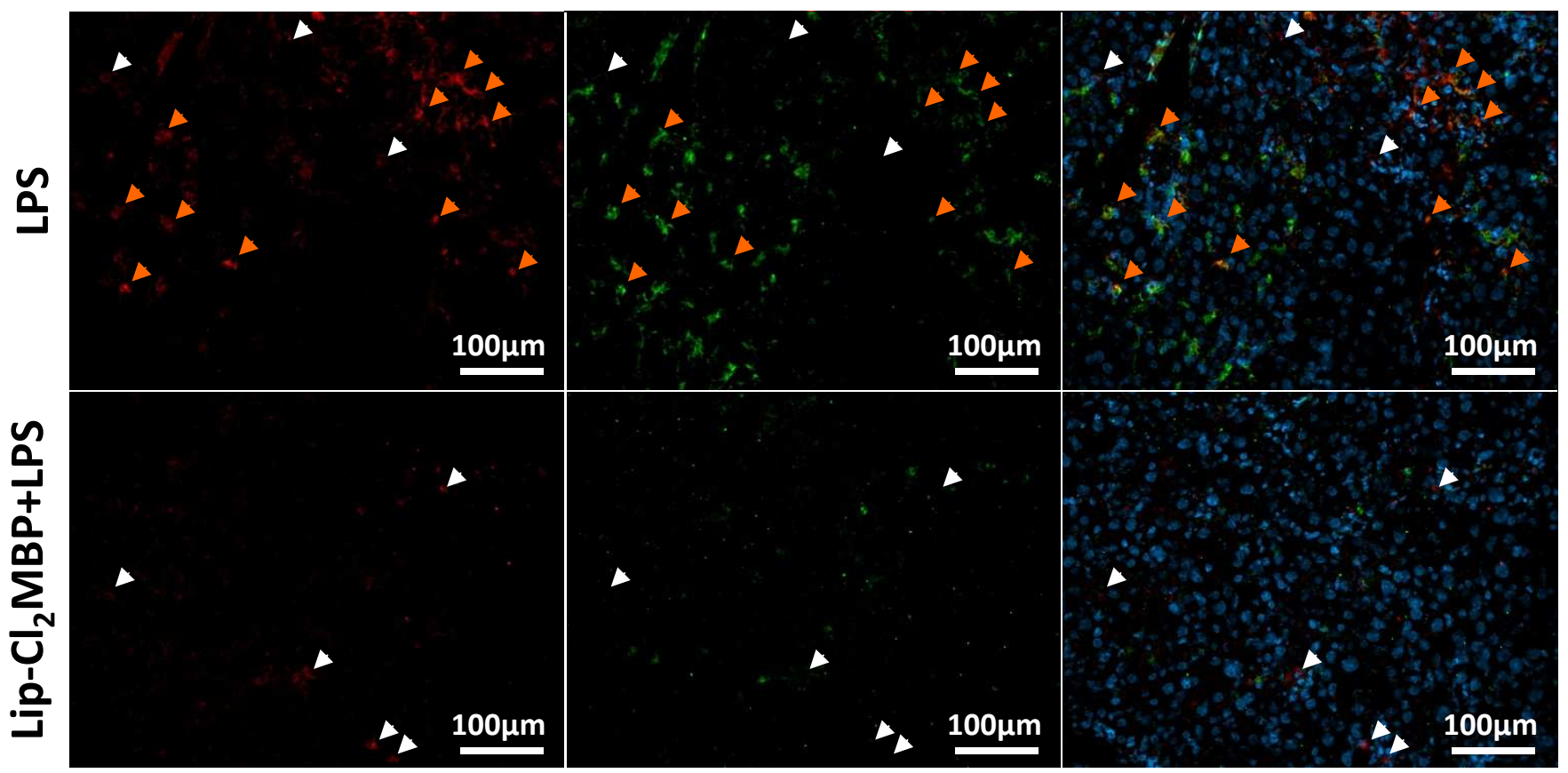




\section{Figure 5}

A

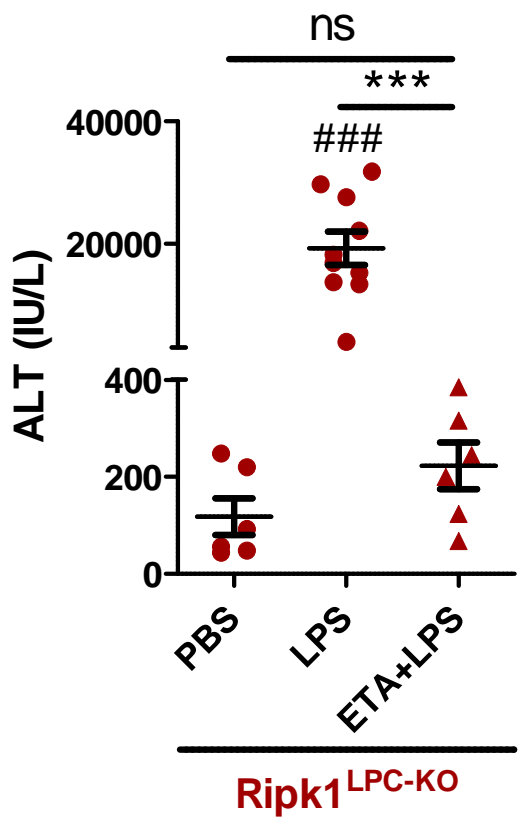

B

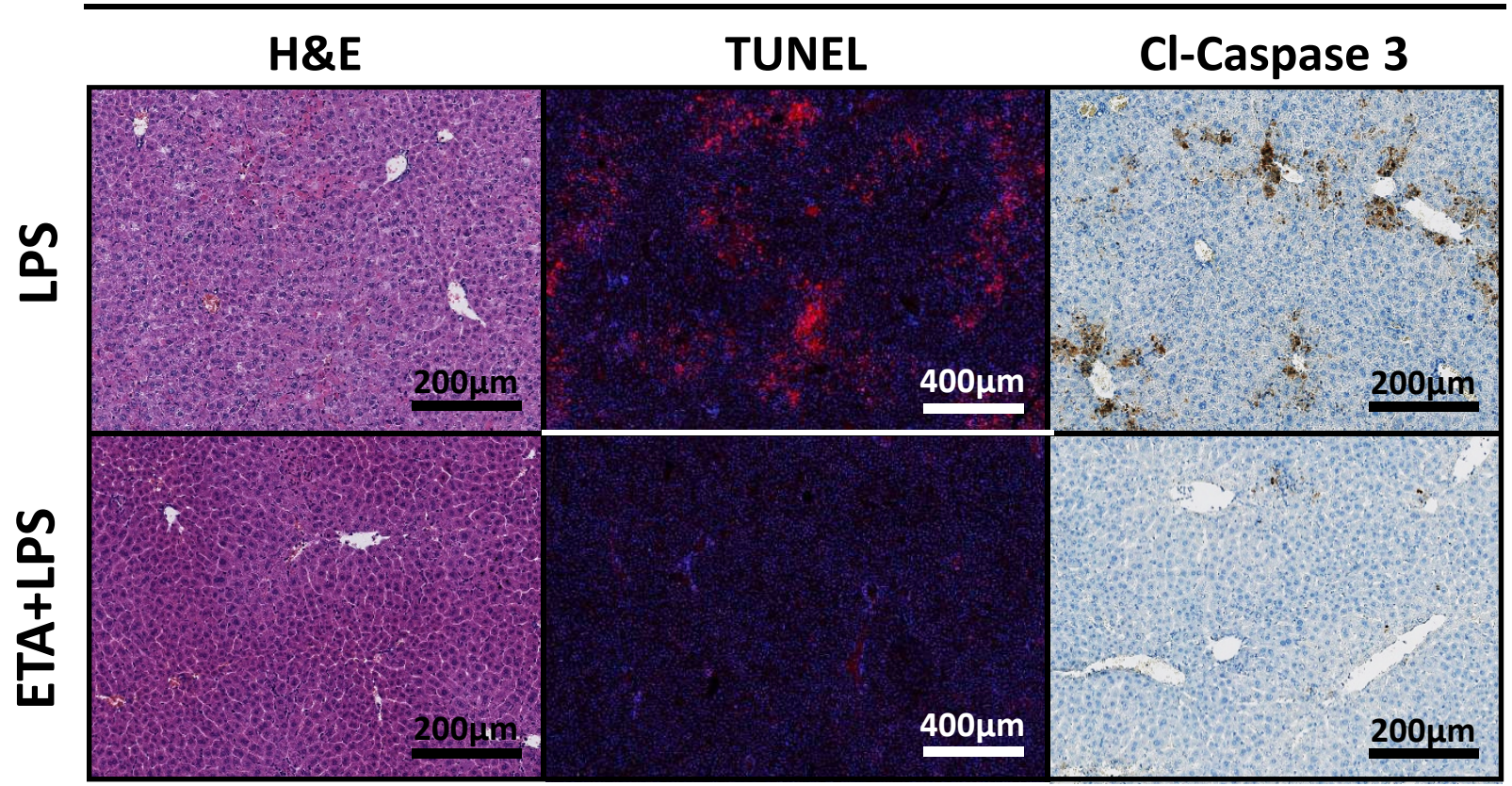

C

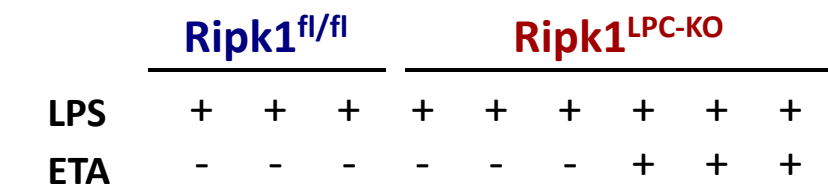

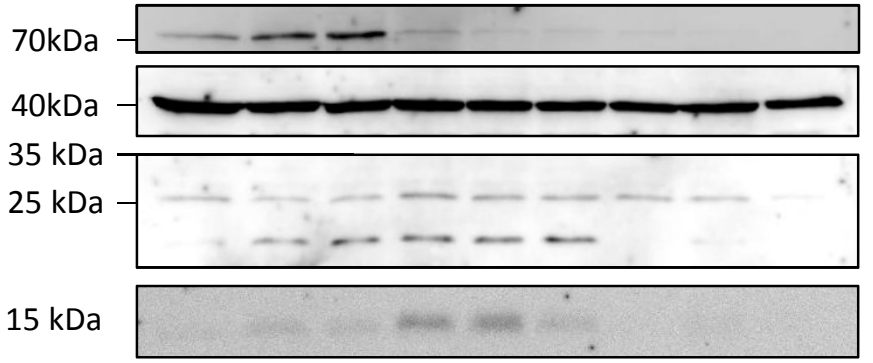

Ripk1

$\beta$-actin

tm-TNF- $\alpha$

s-TNF- $\alpha$

Cl-Caspase 3 
Figure 6

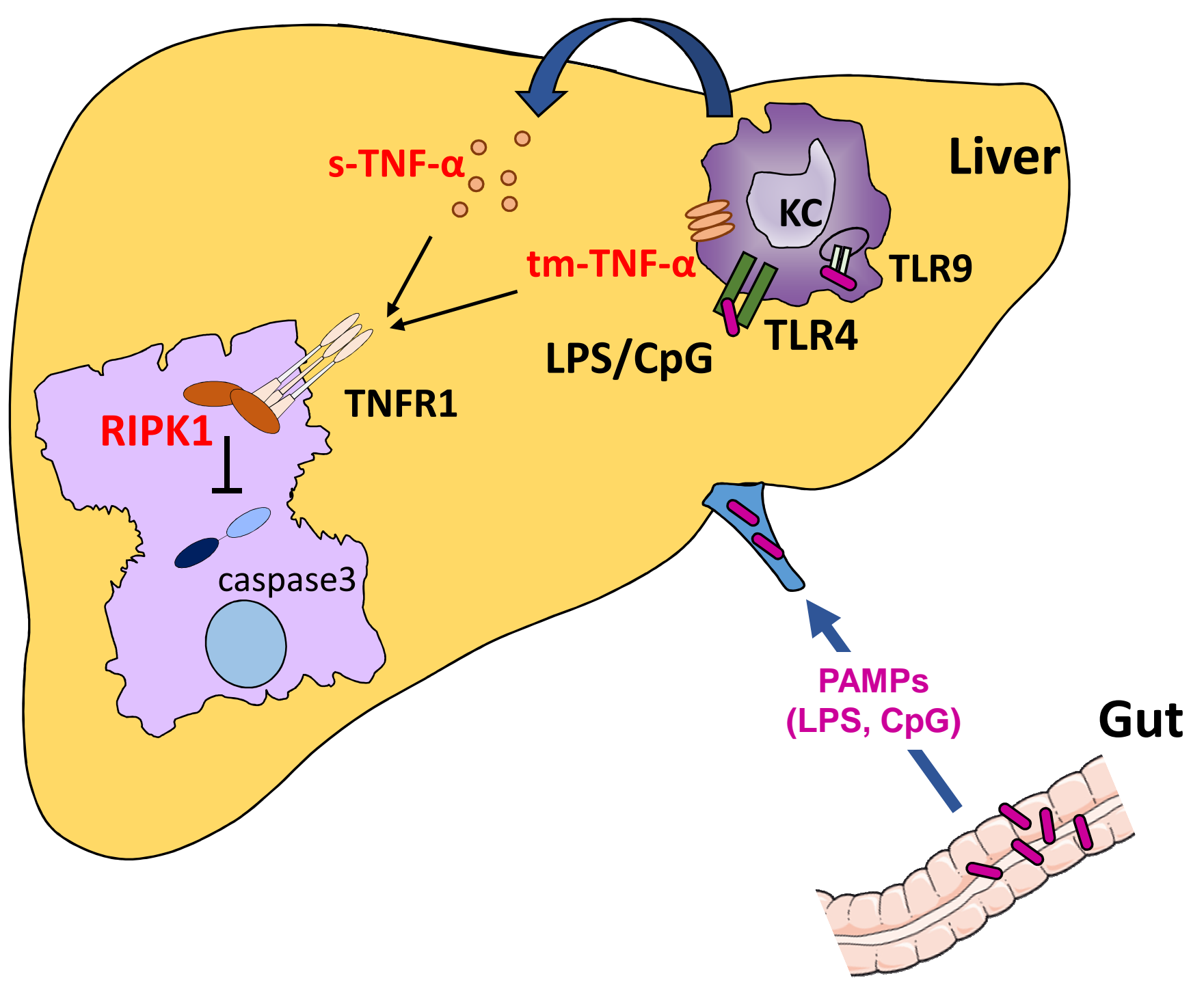




\section{Supplementary figure 1.}

Western-blot analysis of RIPK1 and $\beta$-actin, in protein extracts issued (A) from the liver, (B) or from primary hepatocyte cultures $(\mathrm{PH})$ of WT or Ripk1 $1^{\mathrm{LPC}-K O}$ mice.
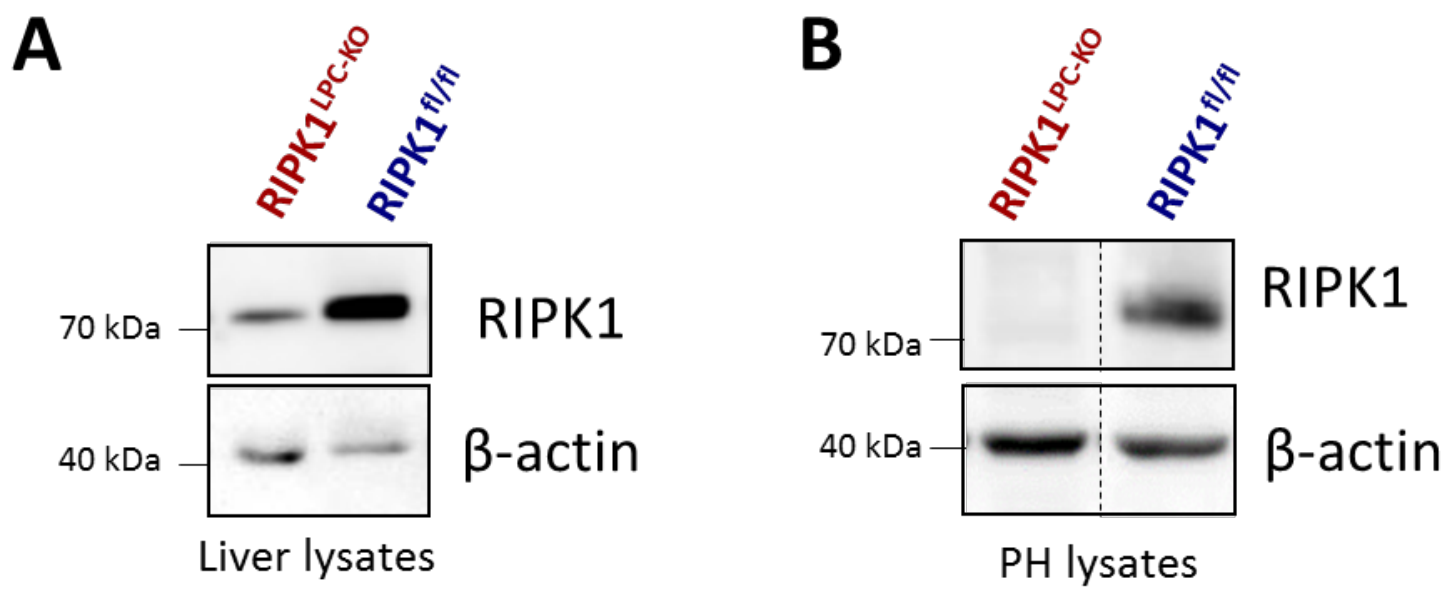


\section{Supplementary figure 2 .}

Levels of hepatic TNF- $\alpha$, MCP1/CCL2 and MIP-1a/CCL3 in Ripk1 $1^{\text {flfl }}$ or Ripk1 ${ }^{\text {LPC-KO }}$ 8.5 $\mathrm{h}$ after PBS $(\mathrm{n}=3)$ or CpG-DNA $(\mathrm{n}=5)$ or LPS $(\mathrm{n}=5)$ administration. Errors bars are expressed as means +/- SEM. Statistical analysis of the data was performed by using the non-parametric Mann-Whitney U-test. $\quad\left({ }^{*}, \#: p<0.05 ; * *\right.$ : $p<0.01 ;$ ns: nonsignificant).

TNF $-\alpha$

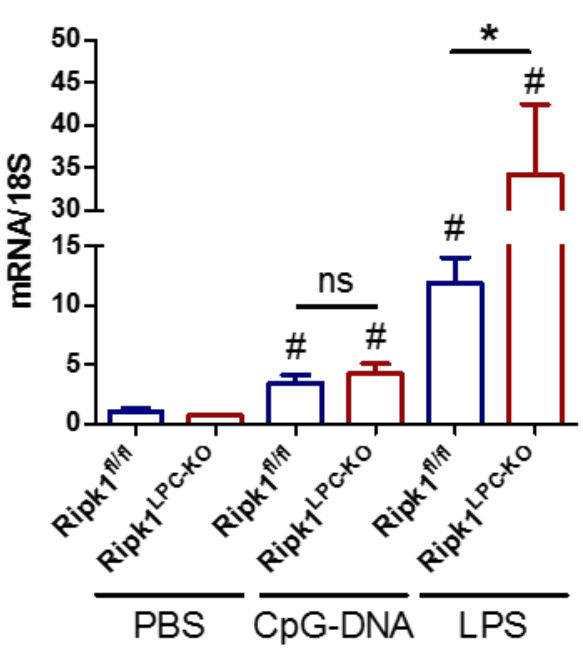

MCP1/CCL2

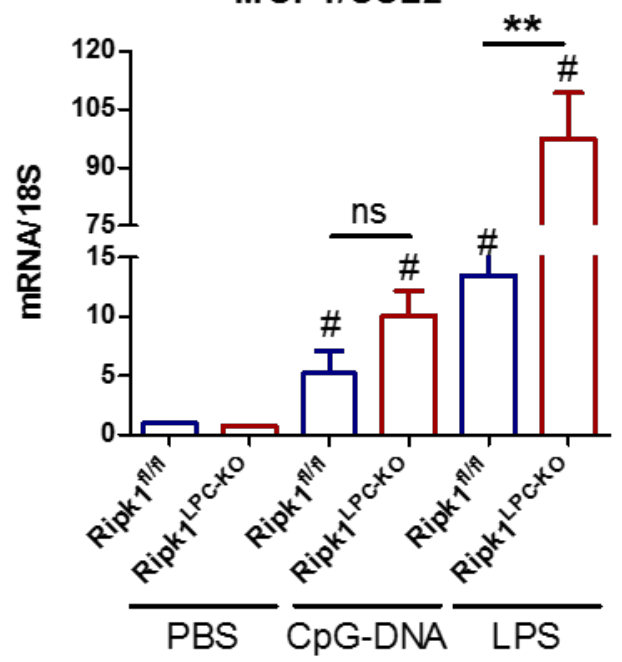

$\mathrm{MIP}-1 \alpha / \mathrm{CCL} 3$

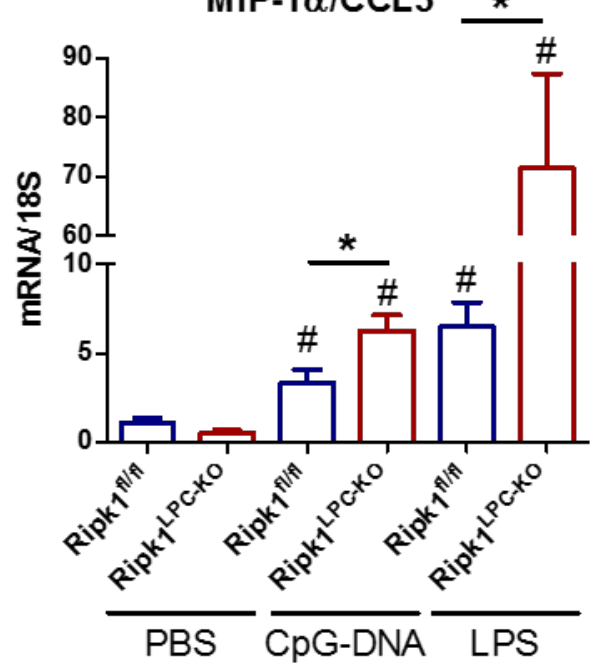




\section{Supplementary figure 3.}

(A) Pictures of liver tissue sections, analyzed by immunohistochemistry for $F 4 / 80$, issued from Ripk1 $1^{\text {LPC-KO }}$ mice $8.5 \mathrm{~h}$ after LPS or PBS injection with an eventual pretreatment during $48 \mathrm{~h}$ with liposomes encapsulated $\mathrm{Cl}_{2} \mathrm{MBP}$ (Lip- $\mathrm{Cl}_{2} \mathrm{MBP}$ ). (B) Serum levels of MIP-1 $\alpha /$ CCL3 and IL-6 collected $1.5 \mathrm{~h}$ after LPS injection $(n=3-5)$. On dot plots, each dot represents an individual and errors bars are expressed as means +/- SEM. Statistical analysis of the data was performed by using the non-parametric Mann-Whitney U-test. ( $\left.{ }^{\star} p<0.05 ;{ }^{* \star} p<0.01 ;{ }^{* \star *} p<0.001\right)$.

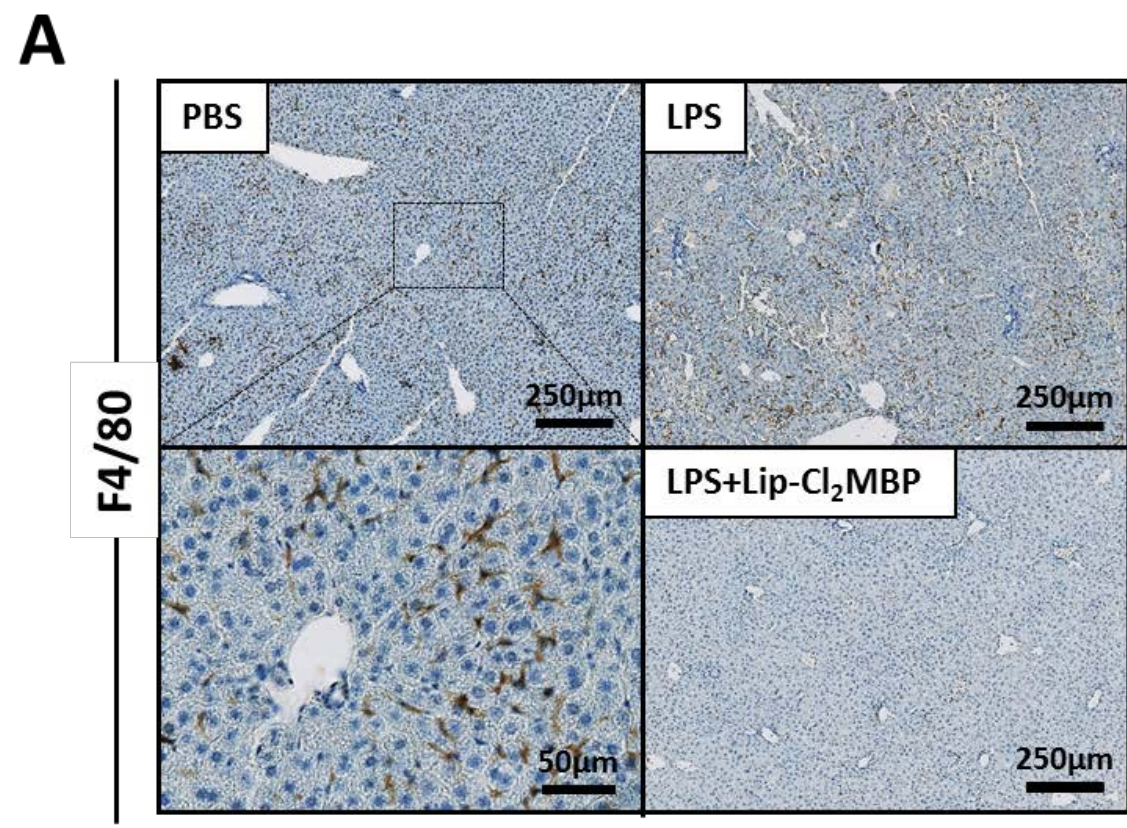

B

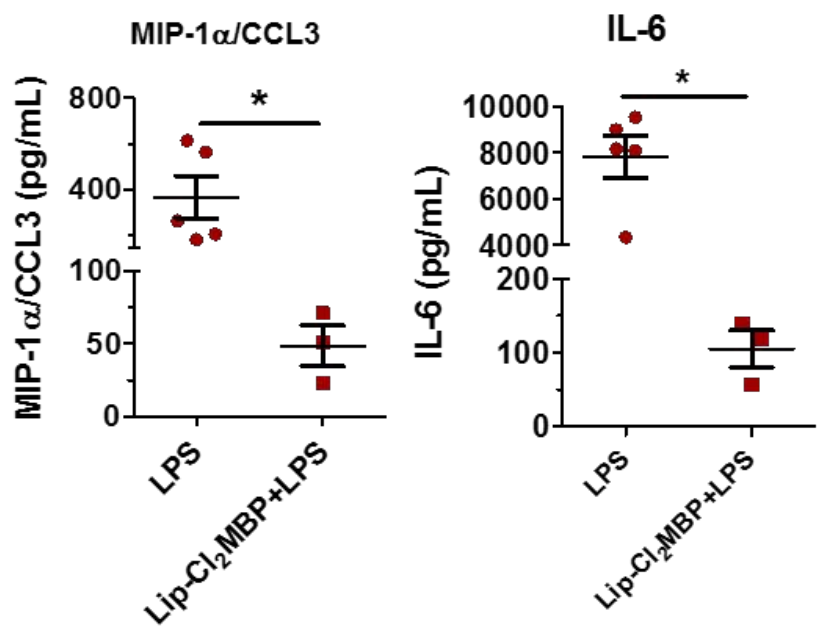




\section{Supplementary Methods}

\section{Primary hepatocytes Isolation and culture}

Hepatocytes were isolated from adult C57BL/6 mice by the retrograde perfusion approach [1]. Mice were previously anesthetized by i.p injection of a ketamine (Imalgene ${ }^{\mathrm{TM}}$, supplier) and xylazine (Rompun ${ }^{\mathrm{TM}}$, supplier) cocktail (60 and $10 \mathrm{mg} / \mathrm{kg}$ of live body weight, respectively) diluted in PBS. After laparotomy, the liver, perfused through inferior vena cava, was first washed with solution I (8 g/L NaCl, $0.2 \mathrm{~g} / \mathrm{L} \mathrm{KCl}$, $0.1 \mathrm{~g} / \mathrm{L} \mathrm{Na}_{2} \mathrm{HPO}_{4} .12 \mathrm{H}_{2} \mathrm{O}$ and $2.38 \mathrm{~g} / \mathrm{L}$ Hepes, $\mathrm{pH} 7.6$ ) at a $5.5 \mathrm{ml} / \mathrm{min}$ flow rate for 8$10 \mathrm{~min}$. Then, the perfusion solution I was supplemented with $5 \mathrm{mM} \mathrm{CaCl} 2 \cdot 2 \mathrm{H}_{2} \mathrm{O}$ and 0.01\% collagenases (Liberase ${ }^{\mathrm{TM}} \mathrm{TM}$ Research Grade, Roche) for 5-7 minutes. Hepatocytes were harvested after 3 centrifugations at $90 \mathrm{~g}$ for $1 \mathrm{~min}$ and an additional purification of viable cells on a percoll cushion. Cell suspensions, with over $90 \%$ viability, were seeded at a density of $0.1 \times 10^{6}$ cells $/ \mathrm{cm}^{2}$ in 24-well plates, previously coated with collagen type I (BD Biosciences, Le Pont de Claix, France), in Williams' $E$ medium supplemented with $10 \%$ (vol/vol) fetal calf serum, $2 \mathrm{mM}$ glutamine, $10 \mathrm{IU} / \mathrm{mL}$ penicillin, $10 \mu \mathrm{g} / \mathrm{mL}$ streptomycin and $5 \mu \mathrm{g} / \mathrm{mL}$ insulin. Seeding medium was removed after a $4 \mathrm{~h}$-period and replaced by a similar supplemented Williams' E medium, except that fetal calf serum was replaced by $1 \mathrm{mg} / \mathrm{mL}$ bovine serum albumin, but with $1 \mu \mathrm{g} / \mathrm{mL}$ of Etanercept. Experimental protocol was conducted in compliance with French laws and the institution's guidelines for animal welfare (agreement of M. Samson \# A3523840).

RNA analysis 
Total RNA was extracted, from mouse liver tissues by using the NucleoSpin RNA II kit (Macherey Nagel \#740955). First-strand cDNA was synthesized using the SuperScriptTM II Reverse Transcriptase (Applied Biosystems). Real-time quantitative PCR was performed using the fluorescent dye SYBR Green with the double-strand specific SYBR Green system (Applied Biosystems) and the CFX384 Touch $^{\text {TM }}$ RealTime PCR Detection System (Bio-Rad). cDNA was used as template for amplification with specific primer pairs : TNF- $\alpha$ (Fwd: 5'-TAGCTCCCAGAAAAGCAAGC-3' ; Rev: 5'-TTTTCTGGAGgGAGATGTGG-3'), CCL2 (Fwd: 5'GTCCCTGTCATGCTTCTGG-3' ; Rev: 5'-TGCTGGTGATCCTCTTGTAGC-3') and CCL3 (Fwd: 5'-CCTTGCTGTTCTTCTCTGTACC-3' ; Rev: 5'AAATGACACCTGGCTGGG-3"). Each measurement was performed in triplicate. The relative gene expression was normalized against the $18 \mathrm{~S}$ gene expression (Fwd: 5'-CGCCGCTAGAGGTGAAATTC-3'; Rev: 5'-TTGgCAAATGCTTTCGCTC-3'). The control mice in each treatment group served as a reference for messenger RNA (mRNA) expression (control mRNA level was arbitrarily set at 1). 


\section{Extended discussion}

The concanavalin A (ConA) model mimics some features of auto-immune or viral hepatitis in mice. Indeed, this lectin activates T-lymphocytes and more specifically NKT subset in an antigen-independent manner $[2,3]$. Thus, hepatocyte death is induced in a DR-dependent manner, also requiring the production of TNF- $\alpha$, IFN- $Y$ and IL-4. Closer to physiopathologic conditions, PAMPs administration allows to study the role of innate immune cells activation, such as Kupffer cells, in the development of hepatitis. Inflammation induced in this condition is important to control bacterial burden but in return it can provoke collateral tissue damage which is a cause of ACLF [4]. In WT animals, ConA induced a complex inflammatory environment which leads to hepatocyte lysis whereas single administration of PAMPs alone is ineffective. Altogether, these characteristics underline the complementarity of both models. The exacerbated liver injury associated with a sustained inflammation (certainly promotes by the release of DAMPs issued from dead hepatocytes) observed in Ripk1 ${ }^{\text {LPC-KO }}$ mice during ConA [5] or PAMPs challenging highlights the importance of RIPK1 as a protector of hepatocytes during immune-cells stimulated conditions and TNF-signaling. These new data enlarge our knowledges on the RIPK1 platform functions in hepatocytes which were until now questioned as recently underlined by Dara and colleagues [6].

\section{References.}

[1] Houseman L, Edwards M, Phillips IR, Shephard EA. Isolation and Culture of Mouse Hepatocytes: Gender-Specific Gene Expression Responses to Chemical Treatments. Methods Mol Biol 2015;1250:3-12.

[2] Tiegs G, Hentschel J, Wendel A. A T cell-dependent experimental liver injury in mice inducible by concanavalin A. J Clin Invest 1992;90:196-203. 
[3] Takahashi K, Kitano A, Akiba Y. Effect of L-carnitine on proliferative response and mRNA expression of some of its associated factors in splenic mononuclear cells of male broiler chicks. Anim Sci J 2010;81:215-222.

[4] Moreau R. The Pathogenesis of ACLF: The Inflammatory Response and Immune Function. Semin Liver Dis 2016;36:133-140.

[5] Filliol A, Piquet-Pellorce C, Le Seyec J, Farooq M, Genet V, Lucas-Clerc C, et al. RIPK1 protects from TNF- $\alpha$ mediated liver damage during hepatitis. Cell Death Dis 2016.

[6] Dara L, Liu ZX, Kaplowitz N. Questions and controversies: the role of necroptosis in liver disease. Cell Death Discov 2016;2:16089. 